\title{
What do non-religious non-believers believe in? Secular worldviews around the world
}

***This manuscript has been accepted for publication in Psychology of Religion and Spirituality***

Valerie van Mulukom ${ }^{1}$

Hugh Turpin ${ }^{2}$

Roosa Haimila ${ }^{3}$

Benjamin Grant Purzycki ${ }^{4}$

Theiss Bendixen ${ }^{4}$

Eva Kundtová Klocová ${ }^{5}$

Dan Řezníček ${ }^{5}$

Thomas J. Coleman III ${ }^{1}$

Kenan Sevinç ${ }^{6}$

Everton Maraldi ${ }^{7}$

Uffe Schjoedt ${ }^{4}$

Bastiaan T. Rutjens ${ }^{8}$

Miguel Farias ${ }^{1}$

${ }^{1}$ Brain, Belief, and Behaviour Lab, Centre for Trust, Peace and Social Relations, Coventry University, Coventry, United Kingdom

${ }^{2}$ University of Oxford, Oxford, United Kingdom

${ }^{3}$ University of Helsinki, Helsinki, Finland

${ }^{4}$ Aarhus University, Aarhus, Denmark

${ }^{5}$ LEVYNA (Laboratory for the Experimental Research of Religion), Masaryk University, Brno, Czech Republic ${ }^{6}$ Canakkale Onsekiz Mart University, Çanakkale, Turkey

${ }^{7}$ Pontifical Catholic University of São Paulo, São Paulo, Brazil

${ }^{8}$ University of Amsterdam, Amsterdam, the Netherlands

*Corresponding author information: Valerie van Mulukom, Coventry University, Centre for Trust, Peace and Social Relations, Coventry, United Kingdom (e-mail: ac2492@coventry.ac.uk).

PLEASE NOTE THAT THIS IS A PRE-PRINT, WHICH HAS BEEN SUBMITTED TO A JOURNAL. WHILE THIS VERSION OF THE DOCUMENT IS THE MOST COMPLETE AND MOST RECENT, IT SHOULD BE REGARDED AS A WORK IN PROGRESS.

WE URGE ANY PARTIES INTERESTED IN THIS WORK TO CONTACT THE LEAD AUTHOR (LISTED ABOVE) FOR FURTHER DETAILS OR UPDATES. WE REQUEST THAT THESE FINDINGS ARE REPORTED AS TENTATIVE, AND THEIR STATUS AS A PRE-PRINT. 


\title{
PREPRINT
}

\begin{abstract}
The global increase in non-religious individuals begs for a better understanding of what non-religious beliefs and worldviews actually entail. Rather than assuming an absence of belief or imposing a predetermined set of beliefs, this research uses an open-ended approach to investigate which secular beliefs and worldviews non-religious non-theistic individuals in 10 countries around the world might endorse. Approximately one thousand participants were recruited $(\mathrm{N}=996$; approximately one hundred participants per country) and completed the online survey. A data-driven coding scheme of the open-ended question about the participants' beliefs and worldviews was created and includes 51 categories in 11 supercategories (agency \& control, collaboration \& peace, equality \& kindness, morality, natural laws $\&$ the here and now, non-religiosity, reflection $\&$ acceptance, science $\&$ critical thinking, spirituality, truth, and other). The 10 most frequently mentioned categories were science, humanism, critical scepticism, natural laws, equality, kindness \& caring, care for the earth, left-wing political causes, atheism, and individualism \& freedom. Patterns of beliefs were explored, demonstrating three worldview belief sets: scientific worldviews, humanist worldviews, and caring nature-focused worldviews. This project is a timely data-driven exploration of the content and range of global secular worldviews around the world, and matches previous theoretical work. Future research may utilise these data and findings to construct more comprehensive surveys to be completed in additional countries.
\end{abstract}

\section{Keywords}

secular beliefs; worldviews; non-religion; atheism; cross-cultural 


\section{PREPRINT}

\section{Introduction}

Both the global increase in individuals who lack religious faith or do not hold religious beliefs (Inglehart, 2021), as well as the concurrent increase in secular organisations and even secular rituals such as humanist weddings and funerals (Engelke, 2014) beg for a better understanding of what 'unbelief' or secular belief entails. Unbelief has been defined as 'a general absence of belief in religious tenets' and 'the state of lacking (especially religious) faith or belief' (Lee \& Bullivant, 2016). Thus unbelief connotes a negative phenomenon, as lacking in religious beliefs, as scoring zero on a continuous religiosity scale (Beit-Hallahmi, 2007). However, while non-believers may not hold religious beliefs, they will still hold distinct ontological, epistemological and ethical beliefs about reality (Coleman et al., forthcoming; Farias, 2013; Lee, 2015). To date, there have been numerous sociological and historical attempts to investigate these beliefs (Brown, 2017; Hout \& Fischer, 2014; Inglehart \& Welzel, 2005; Taylor, 2007; Turner, 1985) and worldviews in general (Droogers, 2014; Johnson et al., 2011; Koltko-Rivera, 2004; Taves et al., 2018), but few quantitative studies. The aim of this study was to empirically investigate the range of secular beliefs and worldviews held by people, as well the variation in these beliefs and worldviews across countries. This exploratory study examines the beliefs and worldviews of approximately 1,000 secular individuals in a set of ten different countries around the world.

The study focused in particular on the worldviews of secular individuals, which was taken to signify the set of beliefs that describe or allow one to understand reality and one's existence within it: "Not all beliefs are worldview beliefs. Beliefs regarding the underlying nature of reality, "proper" social relations or guidelines for living, or the existence or nonexistence of important entities are worldview beliefs. Other beliefs are not." (Koltko-Rivera, 2004, p. 5). Worldviews in this sense can be compared to schemas, which are cognitive structures that provide a template for concrete everyday objects and actions, generalised from direct, face-to-face experience (Johnson et al., 2011). Worldviews, by contrast, are cognitive structures for abstract concepts and hypothetical objects, transmitted culturally (Koltko-Rivera, 2004). Importantly, while one can empirically assess the veracity of schemas, it is less clear how one would disconfirm constituent postulates of a worldview, such as those regarding the nature of human relationships, or the ultimate source of moral guidelines. This means that the disconfirmation of schemas entails simple practical adjustment, whereas the disconfirmation of one's worldview is typically associated with graver psychological consequences (Heine et al., 2006; Jonas et al., 2014): in such personal crises or transformations, one's very sense of reality has been shaken.

Given our definition of worldviews as sets of beliefs about the nature of reality and one's existence within it, it becomes clear that religious belief is not a prerequisite for worldviews, and that worldviews are important for religious believers and non-believers alike (Mauritsen \& van Mulukom, forthcoming). Given that non-religiosity is not institutionalised in the same way as the major religions 


\section{PREPRINT}

are however, it is not clear what the range of beliefs and worldviews of non-religious non-believers or non-theists might be, and whether the beliefs are clustered in sets as they might be in certain faith denominations. Theoretically, such clusters have been suggested: In his seminal review paper on worldviews, Koltko-Rivera presents seven groups of worldviews: human nature, will, cognition, behaviour, interpersonal, truth, world and life (Koltko-Rivera, 2004). Similarly, distinct philosophical categories (e.g., axiology, teleology, epistemology, ontology, cosmology, and praxeology) have later been suggested by others (Johnson et al., 2011; Taves et al., 2018). There is, however, little empirical research investigating these theoretical proposals.

The present research therefore had three main aims: (1) to examine the content and range of secular (i.e., non-religious non-theistic) beliefs and worldviews; (2) to investigate whether secular beliefs cluster together in ways similar to theoretical proposals; and (3) to explore how these different types of beliefs might vary across countries. To this end, an open-ended survey was designed to ask nearly 1,000 secular individuals from ten countries across the globe what their most important worldview, belief, or understanding of the world was. Koltko-Rivera (2004) argues that the complexity of worldviews needs to be embraced, and that future analyses might point out clusters of beliefs within worldviews, and that they should not be imposed theoretically. In line with this argumentation, in order to not put words into the mouths of the participants, and to ensure as broad a range as possible for the secular beliefs and worldviews from our selected countries, an open-ended question format was selected, as well data-informed or 'on-the-fly' coding. This means that there was no coding scheme set up prior to data collection or analysis, but that an ethnographic bottom-up approach was used, whereby the data defined the categories would be used (see Methods).

Our aim was to recruit 100 participants with a 50/50 female/male distribution from ten countries that were selected (here in alphabetical order with universal three-letter codes, or ISO 31661 alpha-3 codes): Australia (AUS), Brazil (BRA), Canada (CAN), Czech Republic (CZE), Denmark (DNK), Finland (FIN), the United Kingdom/Great Britain (GBR), the Netherlands (NLD), Turkey (TUR), and the United States of America (USA), see Figure 1. These countries were chosen as this is where we are internationally based with belief and unbelief expertise. Our samples exhibit cultural, geographical, and economic variety, and have differences in terms of importance given to religion in daily life, see Figure 2 (and SM.1 for exact numbers and references). 


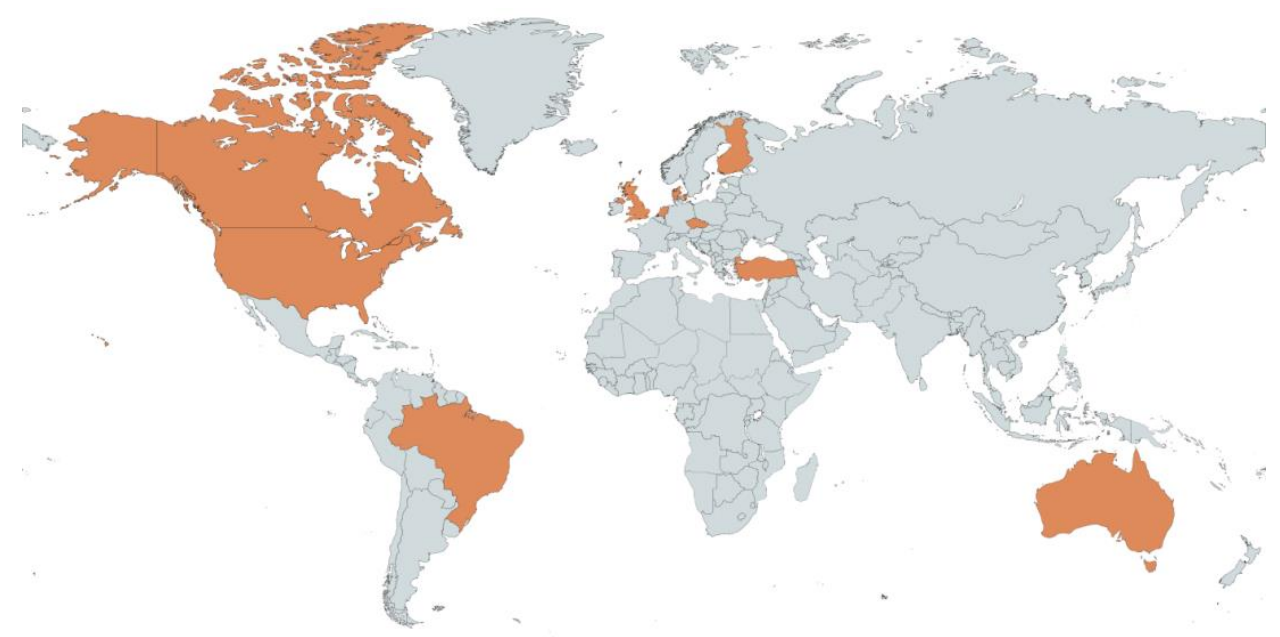

Figure 1. Map of the world with countries (highlighted in orange) from which participants were sampled (figure created through https://mapchart.net/world.html)
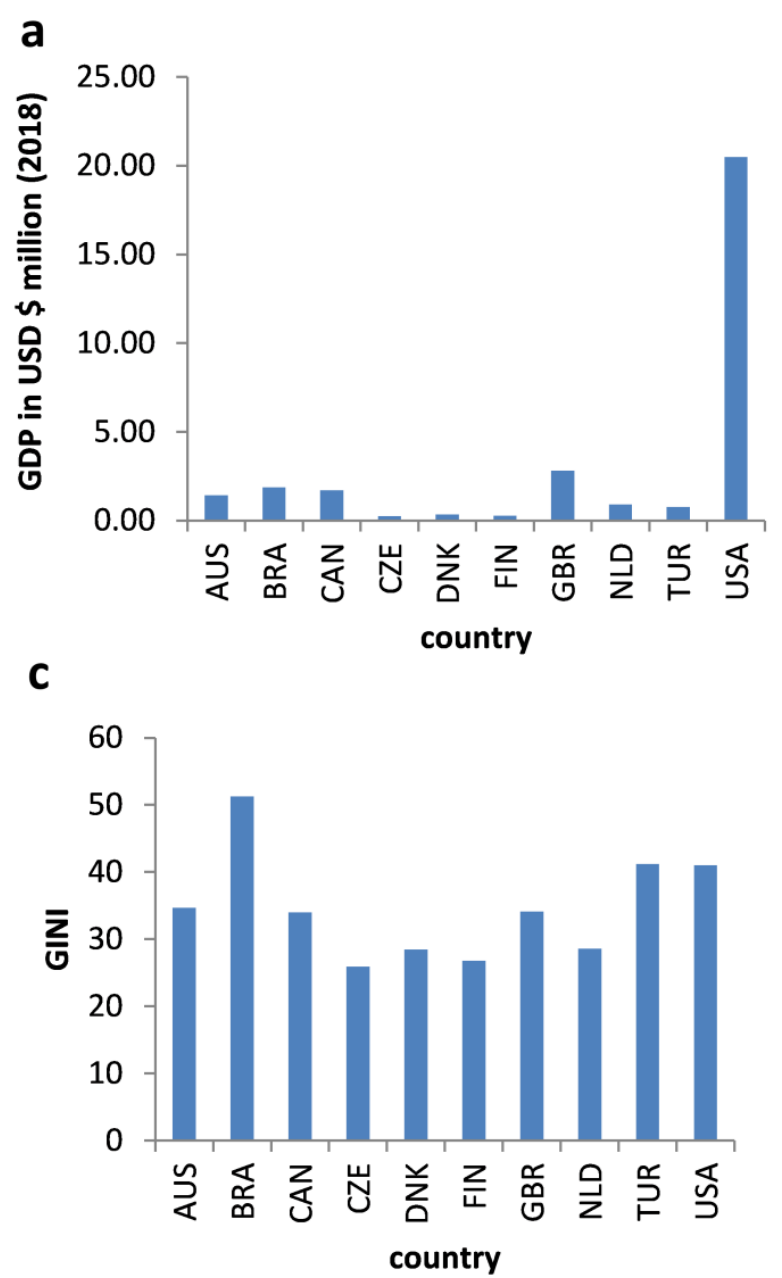

b

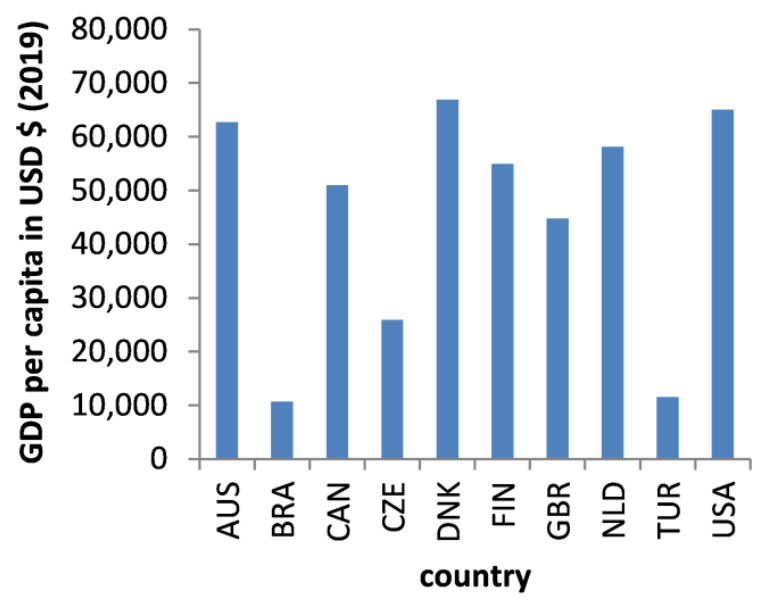

d

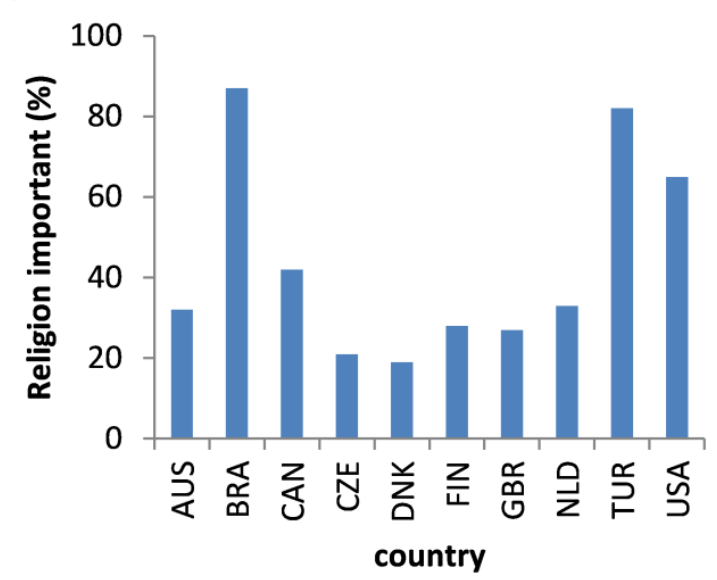

Figure 2. Distribution of (a) country GDP, (b) GDP per capita, (c) GINI, and (d) whether religion is considered important per sampled country. 


\section{PREPRINT}

\section{Methods and measures}

\subsection{Participants}

Participants were recruited through online forums such as Reddit, and relevant Facebook groups and pages in the summer of 2018. As to the desired target population consisted of non-religious nontheistic individuals specifically, ads were placed on pages, websites, and newsletters of atheists, agnostic, and other secular organisations - see Supplementary Materials SM.2 for a list of sources. Participants were not reimbursed for their time but raffles were organised for most countries to stimulate participation numbers.

Two main exclusion criteria for the participants - that they do not believe in God (i.e., are non-theistic) and were not religious - were implemented automatically in the survey, through two questions: (1) "Do you believe in God?" with the option to answer 'Yes' or 'No'. If they ticked 'Yes', the survey automatically ended; and (2) "What is your affiliation?" with the options 'Atheist', 'Agnostic', 'No religion', 'Indifferent', 'Spiritual but not religious', 'Other, namely' and 'Religious'. If they selected 'Religious', the survey ended automatically as well.

Using these recruitment strategies and exclusion criteria, 100 participants were recruited from each country ${ }^{1}$ except for Canada $(n=96)$. For most countries, the planned 50/50 gender distribution was achieved, with exception of Turkey, Czech Republic, and Canada, see Table 1. The gender frequencies however do not differ significantly between the countries $\left(\chi^{2}(9, \mathrm{~N}=996)=10.52, p=\right.$ .31). The age of the participants ranged from 15 to 87 years old and years of education from 5 to 37 years. Age differed significantly between the countries $\left(F(9,979)=29.53, p<.001, \eta_{p}{ }^{2}=.21\right)$, as did years of education $\left(F(9,979)=2.64, p=.005, \eta_{p}{ }^{2}=.02\right)$; see Supplementary Materials SM.1 for posthoc comparisons. Participants were also asked to indicate how spiritual they consider themselves to be on a scale from 0 "Not at all" to 6 "Extremely so" (see Table 1), but not religiosity, as participants had been asked whether they were religious or not beforehand, and all religious individuals were automatically excluded from participation (see above). Average self-reported spirituality differed significantly between the countries $\left(F(9,986)=9.49, p<.001, \eta_{p}{ }^{2}=.08\right)$, see SM.1.

\footnotetext{
${ }^{1}$ In countries where more than 100 participants were recruited, 100 participants were randomly chosen from the pool, whilst maintaining a 50/50 gender distribution. Moreover, participants whose nationality and country of residence matched were selected where possible, in an attempt to obtain 'country-representative' individuals as much as possible.
} 


\section{PREPRINT}

\section{Table 1}

Proportion of gender and means (standard deviations) for age and years of education, and selfreported spirituality per country

\begin{tabular}{lllll}
\hline Country & $\begin{array}{l}\text { Gender } \\
\text { distribution }\end{array}$ & Age (years) & $\begin{array}{l}\text { Years of } \\
\text { education }\end{array}$ & $\begin{array}{l}\text { Self-reported } \\
\text { spirituality }\end{array}$ \\
\hline Australia & $50 \mathrm{~F} / 50 \mathrm{M}$ & $59.1(14.5)$ & $17.4(3.9)$ & $0.60(1.23)$ \\
Brazil & $50 \mathrm{~F} / 50 \mathrm{M}$ & $40.0(13.6)$ & $17.1(4.2)$ & $0.25(0.66)$ \\
Canada & $46 \mathrm{~F} / 50 \mathrm{M}$ & $47.7(12.4)$ & $16.7(3.3)$ & $0.56(1.10)$ \\
Czech Republic & $33 \mathrm{~F} / 67 \mathrm{M}$ & $33.5(10.9)$ & $17.8(4.1)$ & $0.81(1.25)$ \\
Denmark & $50 \mathrm{~F} / 50 \mathrm{M}$ & $46.8(13.4)$ & $17.4(2.8)$ & $0.53(1.05)$ \\
Finland & $50 \mathrm{~F} / 50 \mathrm{M}$ & $44.6(12.9)$ & $18.1(3.8)$ & $1.42(1.59)$ \\
United Kingdom & $50 \mathrm{~F} / 50 \mathrm{M}$ & $49.2(13.1)$ & $17.1(3.9)$ & $0.76(1.32)$ \\
Netherlands & $50 \mathrm{~F} / 50 \mathrm{M}$ & $42.9(14.9)$ & $18.0(3.3)$ & $1.32(1.58)$ \\
Turkey & $44 \mathrm{~F} / 56 \mathrm{M}$ & $35.7(10.9)$ & $16.1(3.8)$ & $1.41(1.86)$ \\
United States & $50 \mathrm{~F} / 50 \mathrm{M}$ & $44.3(14.1)$ & $16.9(3.0)$ & $0.71(1.13)$ \\
\hline average & $47 \mathrm{~F} / 52 \mathrm{M}$ & $44.34(14.76)$ & $17.26(3.68)$ & $0.84(1.37)$ \\
\hline
\end{tabular}

Note. Spirituality was measured on a scale from 0 "Not at all" to 6 "Extremely so".

The frequencies of affiliations or unbeliever labels were also significantly different between the countries (Figure $\left.3 ; \chi^{2}(117, \mathrm{~N}=996)=208.05, p<.001\right)$. However, while most participants indicated they were atheists, many declared in their answers to the open-ended question also to be antitheists or rationalists for example, a label which was not provided by us. Therefore, we consider this label to be a rough indication only. Under 'Other' categories, the most frequently participant-provided labels included 'Antitheist' ( $0.8 \%$ of the total sample across all countries), 'Agnostic atheist' $(0.7 \%)$, Ignostic $(0.3 \%)$, Buddhist (0.2\%), Apatheist $(0.2 \%)$, Rationalist $(0.2 \%)$ and Materialist $(0.1 \%)$, with a further $1.0 \%$ not specified in any of the previously mentioned categories. 


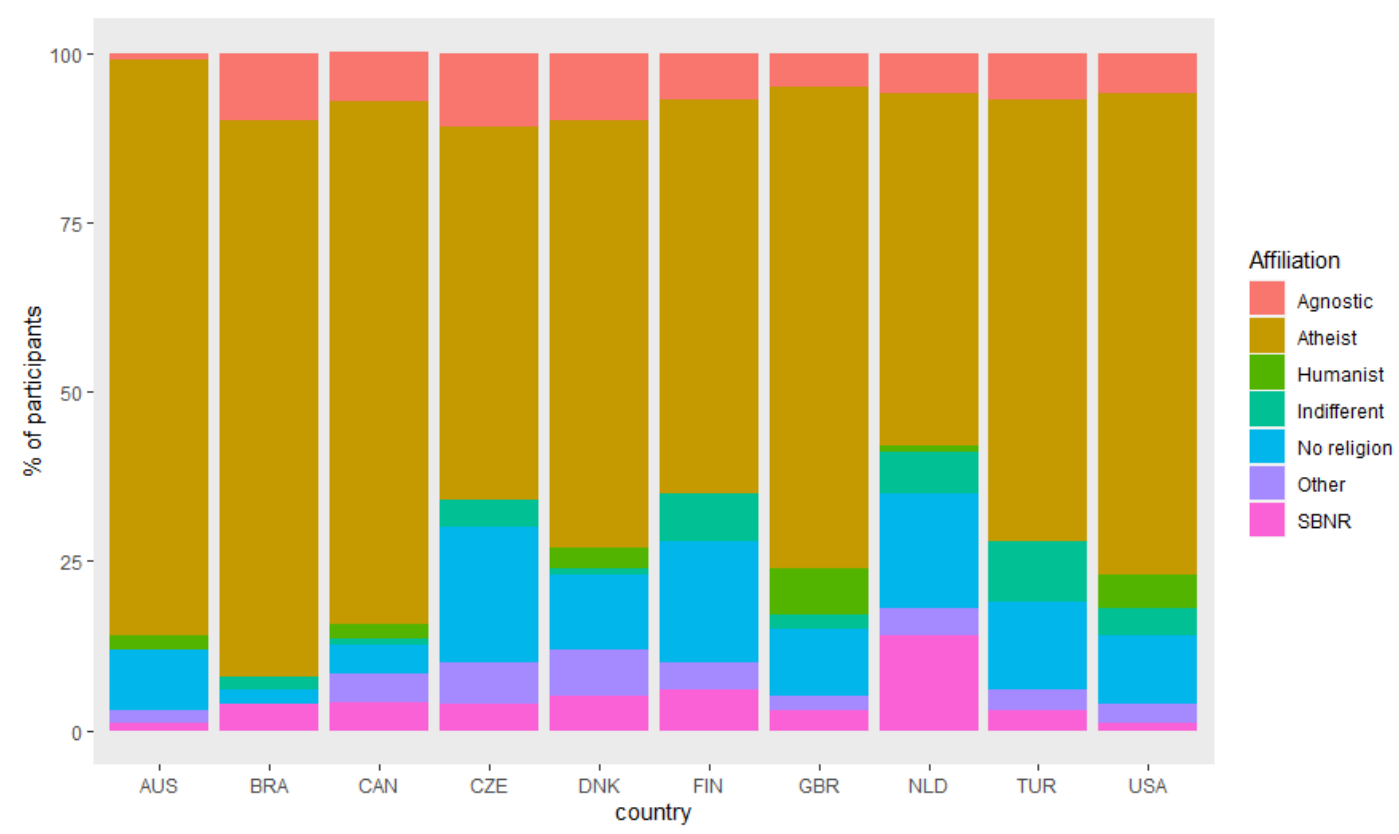

Figure 3. Stacked barplot of percentages of non-religious affiliations of the participants per country

\subsection{Measures}

The data of this study was part of a larger survey. In the present article, the most important worldview(s) the participants held are reported, as well as ratings on a predetermined set of beliefs/worldviews, to explore what the non-religious non-theistic participants believe in.

Most important worldview. Our main aims included to investigate what types beliefs and of worldviews are held by non-religious non-theistic individuals, and how this may vary across countries around the world. As such, as little guidance as possible was given (i.e., no predetermined lists of worldviews), but to make sure that that respondents did not just list their political stance for example, the worldview question was preceded by an explanation of the researchers' stance on secular beliefs and worldviews: "There has been a global increase in individuals who hold no religious affiliation or have no religious beliefs, and a concurrent increase in secular organisations and secular rituals (e.g., humanist weddings and funerals). We are interested in understanding better what forms of "nonreligious belief' entail. While non-believers do not hold religious beliefs, they may still have distinct secular views, for example moral or ethical beliefs or views. Moreover, such secular worldviews may provide non-religious individuals with sources of meaning which are important to explain the world and which may also function as coping mechanisms." This piece of text was followed by: "If you do not believe in God, what worldviews, beliefs, or understandings of the world do you hold? Please list the worldviews, beliefs, or understandings of the world that are particularly meaningful to you." The participants were provided with a text box to type their answers in (with no restrictions to text length).

Beliefs. In addition to the open-ended worldview question, to get an idea of which beliefs/views were adhered to/believed in compared between the different countries, and since we did 


\section{PREPRINT}

not know what to expect from the open-ended questions (providing the participants with a lot of freedom to write either lots or hardly anything), a predetermined list of beliefs was created. This list is based on previous pilot studies and research on unbelief and belief done by the authors of the present article. Participants were asked the question "Which of the following worldviews/understandings of the world/beliefs do you hold? A belief in or a worldview or understanding of the world that primarily relies on" followed by a list of 26 items, see Table 2 below. Participants chose one of the following options for each of the items: "I definitely do not hold this belief/view" (-2), "I do not hold this belief/view" (-1), "Neutral (0), "I hold this belief/view" (1) and "I definitely hold this belief/view" (2). Importantly, this question was asked after the open-ended question so as not to influence the participants' answers there.

Demographics. Participants were asked to indicate their gender (female/male/other), age (in years), and years of education (starting from 1st grade/1st year of primary school). Participants were also asked: "How spiritual do you rate yourself to be?" where they were provided with options ranging from 0 "Not at all" to 6 "Extremely so" (with only number labels in between).

Translations and coding. All translations were done by co-authors on this paper, who were also involved in the coding. For some countries, additional people helped out with the translation and coding. Moreover, three research assistants from Coventry University coded data from United Kingdom, Canada, and Australia. Translation included both the survey and the participants' answers. The survey was translated and back-translated for every country where English is not the first language (Finnish rather than Swedish was used for Finland).

\subsection{Coding procedure}

One of the strengths of this study is the ambition to obtain a data-driven rather than a prespecified/hypothesis-driven description of secular beliefs. Thus, the coding template was developed bottom-up by each of the national co-authors (native speakers), and then agreed upon across countries. First, each national coder identified thematic categories in their datasets, and returned these to the first and second author. The first and second author then integrated identified categories to align the national codes to a common coding template both within and across the countries, and ways to make the number of categories more succinct (some countries had initial coding templates of 200 categories). The new and final coding template, consisting of 51 categories (see Supplementary Materials SM.4 for the full coding template), was sent back to the national coders, who recoded the data of their countries. Finally, the second author (HT) coded every country (according to the template), and through an examination of the difference between the coding, and in discussion between the country's main coder and HT, an agreed coding was settled on for each country, which was then used in the analyses. 


\section{PREPRINT}

The percentage agreement between HT and the country coder ranged from 92.56-96.82\%, with the following agreements per country: United States (92.98\%), Brazil (94.08\%), Denmark (95.38\%), Finland (96.50\%), Turkey (96.62\%), Czech Republic (96.82\%), the Netherlands (93.70\%), United Kingdom (92.56\%), Canada (95.44\%), and Australia (96.02\%). Cohen's kappa was calculated with the formula: $\operatorname{Pr}(\mathrm{a})-\operatorname{Pr}(\mathrm{e}) / 1-\operatorname{Pr}(\mathrm{e})$, whereby $\operatorname{Pr}(\mathrm{a})$ represents the actual observed agreement, and $\operatorname{Pr}(\mathrm{e})$ represents chance agreement (in this case 0.50 as the only scores were present (1) or absent (0)). Cohen's kappa for each of the countries was: United States (0.86), Brazil (0.88), Denmark (0.91), Finland (0.93), Turkey (0.93), Czech Republic (0.94), the Netherlands (0.87), United Kingdom (0.85), Canada (0.83), and Australia (0.92), all >0.80, which we deemed satisfactory.

\section{Results}

\subsection{Predetermined secular belief sets}

The responses to the predetermined belief sets were investigated first, to obtain a baseline beliefs measure irrespective of the variety of the participants' responses. An exploratory principal axis factor analysis was run on the list of provided belief items to examine whether there are certain patterns in the type of beliefs that secular individuals hold. The scree plot tapering off after three factors led to a decision to keep three factors, with a cumulative explained variance of $47.7 \%$. The first factor has an eigenvalue of 6.34 and explains $24.4 \%$ of the variance, the second factor has an eigenvalue of 4.49 and explains $17.3 \%$ of the variance, while the third factor has an eigenvalue of 1.58 and explains $6.1 \%$ of the variance. See Table 2 for the items and factor loadings.

\section{Table 2}

Exploratory factor analysis on predetermined belief items

\begin{tabular}{llll}
\hline Belief/worldview item & F1 & F2 & F3 \\
\hline Science & $\mathbf{- 0 . 4 9}$ & $\mathbf{0 . 4 0}$ & $\mathbf{0 . 5 0}$ \\
Logic/reason & -0.37 & $\mathbf{0 . 4 4}$ & $\mathbf{0 . 4 3}$ \\
Common sense & 0.06 & $\mathbf{0 . 4 7}$ & 0.03 \\
Nature & 0.12 & $\mathbf{0 . 5 4}$ & 0.08 \\
Natural order/Order of the universe & 0.16 & $\mathbf{0 . 5 0}$ & 0.01 \\
Chance/randomness & -0.10 & 0.27 & 0.07 \\
Big Bang & -0.30 & 0.36 & 0.33 \\
Evolution & $\mathbf{- 0 . 4 4}$ & $\mathbf{0 . 4 1}$ & 0.25
\end{tabular}




\begin{tabular}{|c|c|c|c|}
\hline Progress & -0.07 & 0.51 & 0.11 \\
\hline Morality/moral truths/ & -0.02 & 0.55 & -0.03 \\
\hline \multicolumn{4}{|l|}{ Doing and/or being just or good } \\
\hline Humanity/Human ability & -0.04 & 0.66 & -0.13 \\
\hline Human goodness/love & 0.12 & 0.63 & -0.24 \\
\hline Emotions/feelings/gut feelings & 0.34 & 0.56 & -0.22 \\
\hline Self & 0.15 & 0.50 & -0.14 \\
\hline Enjoyment/Seize the day attitude & 0.10 & 0.39 & -0.11 \\
\hline Soul & 0.76 & 0.09 & -0.03 \\
\hline Karma & 0.74 & 0.15 & -0.02 \\
\hline Fate/Destiny & 0.61 & 0.00 & -0.04 \\
\hline Positive thinking & 0.36 & 0.39 & -0.11 \\
\hline Universal consciousness/awareness & 0.59 & 0.28 & -0.10 \\
\hline Energy/energies & 0.67 & 0.20 & -0.08 \\
\hline Spiritual realm/beings & 0.78 & -0.06 & 0.18 \\
\hline A creator & 0.63 & -0.14 & 0.34 \\
\hline A higher power & 0.72 & -0.12 & 0.36 \\
\hline Afterlife & 0.76 & -0.14 & 0.26 \\
\hline Reincarnation & 0.76 & -0.13 & 0.20 \\
\hline
\end{tabular}

Note. Items with a factor loading of $<.40$ or $>-.40$ are in bold.

Factor 1 includes the endorsement of more spiritual beliefs such as soul, karma, afterlife, reincarnation and a higher power is combined with a lack of endorsement for belief in science and evolution. This set of beliefs reflects that of the 'spiritual but not religious individuals' (Fuller, 2001; Lindeman et al., 2019), also called 'spiritual seekers' (Manning, 2015), and appears to emphasise ontology and cosmology. Factor 2 includes not only science, logic, evolution, natural order, progress, but also a belief in human ability and goodness, and similar human-centric values such as belief in the self and belief in emotions. We suggest that these beliefs together reflect a 'secular humanist' package (Lee, 2015; Taylor, 2007; Turner, 1985). These beliefs appear to focus on epistemology, axiology, and praxeology. Notably, two beliefs - belief in seizing the day, and a belief in positive thinking - fall just short of the threshold of factor loadings of $>.40$, with a .39 factor loading for Factor 2 . Belief in 


\section{PREPRINT}

the Big Bang falls short with a factor loading of .36, thus differentiating it from beliefs in science and evolution, which currently may not be at the forefront of people's minds and worldviews. Factor 3 is comprised of just belief in science and in logic and reason. This belief set appears particularly fitting for individuals who have been described as 'philosophical secularist' (Manning, 2015) and 'intellectual atheist/agnostic' individuals (Silver et al., 2014) who proactively try to educate themselves and acquire knowledge in the search for truth (ontology) and enjoy discussing the epistemological positions (epistemology).

The scores for each belief set for each participant were calculated by averaging all items loading into each belief set (Spiritual Beliefs, $\alpha=.891$; Humanistic Beliefs, $\alpha=.797$; Belief in Science \& Logic, $\alpha=.809$ ). On a range from -2 ("I definitely do not hold this belief/view") to 2 ("I definitely hold this belief/view"), Spiritual Beliefs scored negatively on average ( $M=-1.43, S D=$ 0.63) indicating an average lack of endorsement for the individuals of this overall sample, with Humanistic Beliefs $(M=1.15, S D=0.51)$ and Belief in Science \& Logic scoring positively on average $(M=1.74, S D=0.53)$, indicating endorsement (see SM.3 for averages for each of the belief sets per country). Given the composition of our sample - that is, high numbers of participants selecting an atheist label and lower numbers selecting the spiritual but not religious label - we suggest that these results are not unexpected.

\subsection{Open-ended secular belief and worldview question}

\subsubsection{Belief categories and worldview supercategories}

Next, we turn to the open-ended question about the participants' most important secular beliefs and worldviews. First, the final coding scheme will be presented. In this coding scheme the final 51 categories were grouped in 11 supercategories of secular beliefs, see Figure 4 (see Supplementary Materials SM.4 for the full coding template). 


\section{Coding categories}

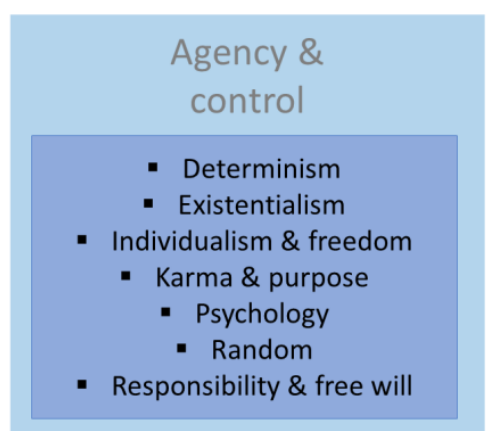

\section{Morality}

- Acquired morality

- Intuitive morality

- Rational morality

- Secular morality

- Unspecified morality

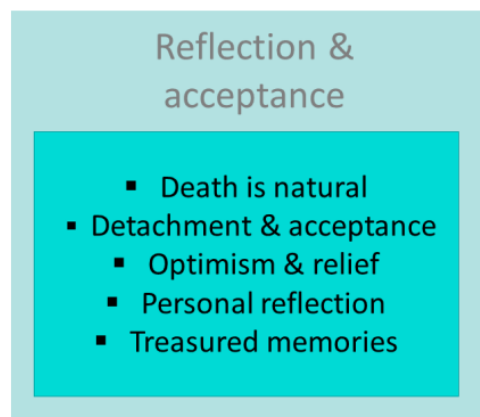

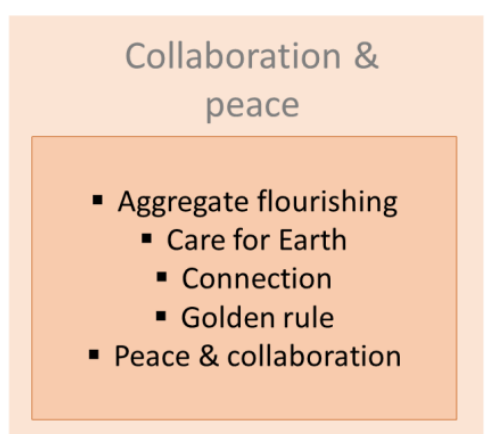
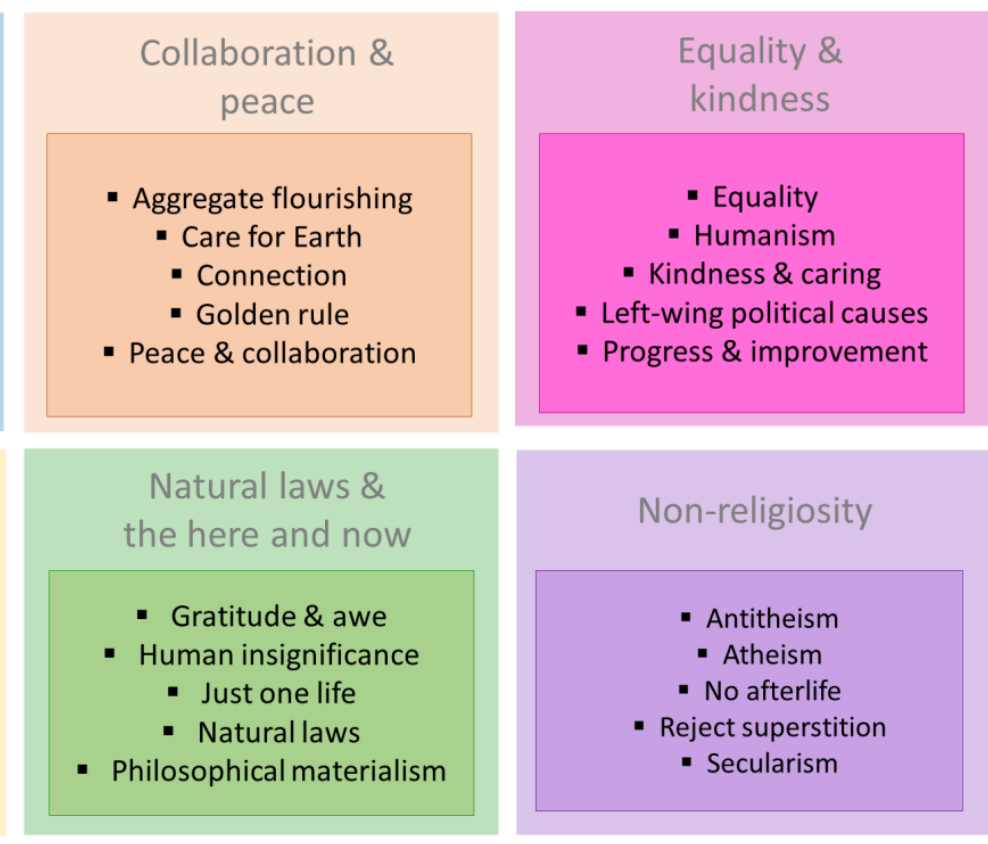

Science \& critical thinking

- Critical scepticism

- Science
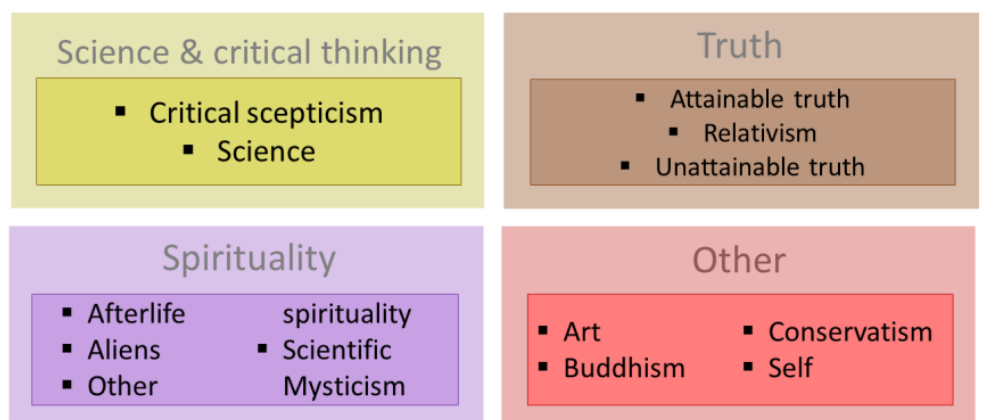

Figure 4. Overview of all 51 coding categories of the template within their 11 super-categories (both categories and super-categories are ordered alphabetically with 'Other' added last; colours hold no particular significance and are used for visual assistance)

Next, the supercategories were compared to previously proposed theoretical components, see Table 3 . There is a relatively good match with the theorised components; the only category which we were not able to place is the 'other' category, which is unsurprising given its idiosyncratic contents. Nonreligiosity is the only category occurring twice: both in the 'epistemology'/"world and life' component, and in the 'ontology-cosmology'/'cognition; truth' component. 


\section{PREPRINT}

\section{Table 3}

Theoretical proposals of worldview categories matched with the categories found in the present research

\begin{tabular}{|c|c|c|c|c|}
\hline $\begin{array}{l}\text { Koltko-Rivera } \\
\text { (2004) }\end{array}$ & $\begin{array}{l}\text { Johnson et } \\
\text { al. (2011) }\end{array}$ & $\begin{array}{l}\text { Taves et al. } \\
\text { (2018) }\end{array}$ & present study & description \\
\hline $\begin{array}{l}\text { Human nature; } \\
\text { Behaviour } \\
\text { (moral) }\end{array}$ & Axiology & Axiology & Morality & $\begin{array}{l}\text { What is the good that we } \\
\text { should strive for, what is } \\
\text { good and evil }\end{array}$ \\
\hline $\begin{array}{l}\text { Will; Behaviour } \\
\text { (control) }\end{array}$ & Teleology & - & $\begin{array}{l}\text { Agency \& control; } \\
\text { Reflection \& } \\
\text { acceptance }\end{array}$ & $\begin{array}{l}\text { What can we control, do } \\
\text { we have free will }\end{array}$ \\
\hline Cognition; Truth & $\begin{array}{l}\text { Episte- } \\
\text { mology }\end{array}$ & $\begin{array}{l}\text { Episte- } \\
\text { mology }\end{array}$ & $\begin{array}{l}\text { Science \& critical } \\
\text { thinking; Truth; Non- } \\
\text { religiosity }\end{array}$ & $\begin{array}{l}\text { What can we know, how } \\
\text { do we know what is true, } \\
\text { how should we reason }\end{array}$ \\
\hline World and life & Ontology & $\begin{array}{l}\text { Ontology; } \\
\text { Cosmology }\end{array}$ & $\begin{array}{l}\text { Natural laws \& the } \\
\text { here and now; Non- } \\
\text { religiosity; Spirituality }\end{array}$ & $\begin{array}{l}\text { What exists, what is real; } \\
\text { Where do we come } \\
\text { from and where are we } \\
\text { going (incl. afterlife) }\end{array}$ \\
\hline $\begin{array}{l}\text { Interpersonal; } \\
\text { Behaviour } \\
\text { (moral) }\end{array}$ & Praxeology & Praxeology & $\begin{array}{l}\text { Collaboration \& } \\
\text { peace; Equality \& } \\
\text { kindness }\end{array}$ & $\begin{array}{l}\text { What actions should we } \\
\text { take (in particular within } \\
\text { the context of } \\
\text { communities) }\end{array}$ \\
\hline
\end{tabular}

Next the categories which were mentioned most often across all countries were investigated. The top ten most named categories across all countries are listed in Table 4 below, with the percentage of participants mentioning each particular category. After the global top ten, all other categories are mentioned by $8.4 \%$ of the participants or less.

\section{Table 4}

Global top ten of most frequently mentioned belief/worldview categories

Category \% Description

Science $\quad 35.1$ Responses that endorse science in general, scientific methodology or perspectives (including responses such as believing in 'evidence' or 'observations' or methodological naturalism), or scientific expertise and authority (including responses indicating a trust in scientific and medical experts).

Humanism 25.5 Responses that fall under the general umbrella of humanism or related worldviews, including beliefs that human beings are special (human relativism), 
that human history is inherently progressive, that human reason or ingenuity can overcome all problems (belief in human ability).

Critical $\quad 17.4$ Responses that espouse the value of a questioning, critical disposition towards Scepticism information. It includes responses that simply state a belief in 'scepticism', 'rationalism', 'logic', and 'reason' but also answers that include belief in mathematics, philosophy or philosophical reasoning. In addition, answers indicating belief in open-mindedness and the ability to change your beliefs were included here as well.

Natural $\quad 15.6$ Responses that talk about the laws underlying biological or physical systems, Laws and/or emphasise that humans are subject to the same laws as the rest of the physical universe. This includes answers reflecting a belief in nature, naturalism and biology. Answers that indicate a belief in 'Big Bang', and 'Evolution' are also included here, as well as statements such as "We are all made of stardust/particles, and we will return to this when we die".

Equality $\quad 14.0$ Responses that emphasise the equality of human beings, their inherent value or dignity, the importance of legal or philosophical innovations ensuring such equality is respected (such as democracy and human rights), and the general obligation to make society more equal (including universal healthcare and general (rational) care for all humans).

Kindness $\quad 13.6$ Responses that praise the importance of empathy or concern for others, and/or \& Caring the importance of caring actions, and helping and supporting others. It includes beliefs in human goodness and kindness (though not human ability, see Humanism) and beliefs in compassion, empathy, being kind and loving, and love. It encompasses belief in a more intuitive rather than rational care (see Equality).

Care for $\quad 11.5$ Responses that emphasise the importance of environmentalism, looking after the Earth the planet, and respecting and caring for other species, including beliefs in care and respect for all flora and fauna, and in animal rights. It also includes the belief that we have a legacy, and that we need to leave the Earth in a good state for future generations.

Left-Wing $\quad 10.1$ Responses that mention a cause or worldview associated with left-wing politics Political (regardless of actual mentioning of left-wing politics). This category includes Causes feminism, socialism, Marxism, and Anarchism, as well as being a vegetarian, pro-choice, pro-euthanasia and an advocate for LGBTQ.

Atheism $\quad 9.9 \quad$ Responses that reject religious belief, particularly a belief in God. However, this category does not include responses that adopt a negative or critical stance towards belief in God (Antitheism), or those that focus on the separation between state and Church (Secularisation), a rejection of belief in an afterlife (No afterlife), a rejection of belief in the supernatural more generally (Reject superstition), or an endorsement of a belief in secular morality (Secular morality).

Individua- 9.8 Responses that emphasise the importance of individual liberty (including lism \& answers that simply state 'Individualism' or 'Libertarianism'), and/or advocate Freedom resisting the imposition of excess constraints on behaviour. This category includes responses that indicate a belief in freedom of speech or freedom more broadly, and that state 'live and let live'.

To investigate whether participants globally responded in a systematic way, a principal components analysis with varimax rotation was conducted on the data of all participants (all countries) for the top 


\section{PREPRINT}

ten categories. Three factors were extracted, and varimax rotation was used to create three maximally orthogonal factors (i.e., every item -in this case the category- loads maximally onto one of the three factors), since there likely is overlap between the categories. The result of the analysis showed that there are three significant factors - see Table 5 below. Of the entered categories, only atheism did not load on any of the factors despite a varimax rotation, indicating that atheism is not connected uniquely to any one of these factors.

\section{Table 5}

Global response patterns for the global top ten of category frequencies

\begin{tabular}{llll}
\hline & F1 & F2 & F3 \\
\hline Equality & $\mathbf{0 . 6 3}$ & -0.04 & 0.39 \\
Left-Wing Political Causes & $\mathbf{0 . 5 9}$ & 0.07 & 0.10 \\
Individualism \& Freedom & $\mathbf{0 . 5 2}$ & -0.06 & -0.03 \\
Humanism & $\mathbf{0 . 4 3}$ & 0.24 & -0.23 \\
Care for the Earth & 0.22 & -0.03 & $\mathbf{0 . 6 7}$ \\
Critical Scepticism & 0.16 & $\mathbf{0 . 6 8}$ & -0.11 \\
Atheism & -0.03 & 0.03 & -0.07 \\
Science & -0.11 & $\mathbf{0 . 8 1}$ & 0.02 \\
Kindness \& Caring & -0.15 & -0.03 & $\mathbf{0 . 6 2}$ \\
Natural Laws & -0.35 & 0.21 & $\mathbf{0 . 4 1}$ \\
\hline
\end{tabular}

Note. Factor loadings are reported; factor loadings $>.40$ in bold.

The first factor we might call the left-wing humanist responses (or care for humans). It bears resemblance to Lee (2015)'s definition of humanism, though with more focus on praxeology than Lee's conceptualisation, which emphasises epistemology. The second factor we might call the scientific sceptic responses (or how to think), which emphasises epistemology. Given that this factor includes both belief in science and critical scepticism, it might include individuals who are not necessarily convinced about the 'truth' of current scientific knowledge but ascribe to the scientific method as a meaningful worldview. Thus, this component might overlap with previously described worldview types that value an open disposition towards knowledge, such as 'seeker agnostics' in Silver et al. (2014), but also other non-theists who are attuned to the intellectual, such as analytic atheists in Lindeman et al. (2019) or 'intellectual atheist/agnostic' individuals in Silver et al. (2014) and possibly 'philosophical secularists' in Manning's (2015) typology. The third factor we might call the environmental caring responses (or care for earth and acceptance of nature). These responses focus on humans as a natural part of nature and hence nothing 'special' (Haimila \& Muraja, 2021; Zuckerman, 2020) and also indicate an interconnectedness, as discussed in the existential culture of agnosticism (Lee, 2015), thus combining cosmology/ontology with praxeology. 


\section{PREPRINT}

To further investigate possible connections with other belief sets, a correlation analysis was conducted with the predetermined belief sets (see section 3.1), see Table 6. The correlations between scientific sceptic beliefs and the pre-determined belief sets are as predicted: negative correlations with spiritual beliefs, and positive correlations with science and logic beliefs. The other correlations are somewhat more surprising however: left-wing humanist beliefs do not correlate with humanist beliefs $(p=.08)$, but like scientific sceptic beliefs correlate negatively with spiritual beliefs and positively with science and logic beliefs. Environmental caring beliefs did not correlate significantly with any of the predetermined belief sets, with a trend for a positive correlation with humanist beliefs $(p=.06)$. One reason for these somewhat surprising findings might be that these correlations are run across countries, and there may be differences in correlations between the countries. However, the countrylevel sample size, while sizable for open-ended questions, is too small to run sufficiently powered correlations, so we are not able to further examine this possibility.

\section{Table 6}

Correlations between open-ended secular belief sets and predetermined belief sets

\begin{tabular}{lccc}
\hline & Spiritual beliefs & Humanist beliefs & $\begin{array}{c}\text { Science \& logic } \\
\text { beliefs }\end{array}$ \\
\hline Left-wing humanist & $-.11^{* *}$ & $.06 \#$ & $.09^{* *}$ \\
beliefs & {$[-.17,-.05]$} & {$[-.01, .12]$} & {$[.03, .15]$} \\
Scientific sceptic & $-.20^{* *}$ & -.04 & $.16^{* *}$ \\
beliefs & {$[-.26,-.14]$} & {$[-.10, .02]$} & {$[.10,22]$} \\
Environmental & .01 & $.06 \#$ & .02 \\
caring beliefs & {$[-.05, .08]$} & {$[-.00, .12]$} & {$[-.04, .09]$} \\
\hline
\end{tabular}

Note. Correlations for 995 observations. ${ }^{* *} p<.01, \# p<.10$.

\subsubsection{Cross-cultural variation in secular beliefs and worldviews}

Finally, the top ten categories of each country were examined, and how they might differ, see Table 7. As is visible from this table, all countries' top ten lists contain categories that are mentioned in 9-59\% of the participants' responses, with the most intra-country agreement for Canada, in which $11-59 \%$ of the responses include the top ten categories, and the least agreement for the Netherlands, where the top ten categories only cover 9-24\% of the Netherlands's responses. Interestingly, the top ten most frequently named categories are very similar across the different countries, despite the geographical spread and cultural differences between the countries (see Table SM5.1 for an overview of the cultural distance between the countries, Muthukrishna et al., 2020). In particular, the six top 


\section{PREPRINT}

categories occur frequently in each of the countries separately: Science, Critical Scepticism, Natural Laws, and Humanism, Equality, and Kindness \& Caring.

Together, these six frequently occurring categories seem to reflect a worldview based on scientific, critical thinking and human-centred values surrounding equality and care, and is consistent with prior descriptions on the belief systems of secular group affiliates (Pasquale, 2009; Smith, 2017; Smith \& Halligan, 2021). Many have noted the importance of the scientific and humanistic frameworks for secular individuals (e.g., Bullivant et al., 2019; Lee, 2015), and in some studies these provide a common ground for the worldviews of secular group affiliates (Kontala, 2016). Furthermore, scholars such as Pasquale (2009) and Bullivant et al. (2019) have previously reported the importance of intuitive care (e.g., compassion, friendship) and rational care (human dignity, equality) for secular individuals' sense of meaning in life and the world.

Differences between the top ten lists of the different countries are interesting also - a few categories appeared where they were not necessarily expected, or lacked where they may have been expected. For example, while left-wing political causes ranks first in Turkey, this category does not occur at all in the top ten of Denmark or Finland. This may be considered surprising given what is known about these countries: left-wing political causes such as abortion and euthanasia are currently forbidden in Turkey, while Denmark and Finland are some of the most progressive, left-wing countries on earth. We suggest here that what these most frequently named categories reflect is the current political or societal climate in these countries in interaction with the country-specific secular identities. Thus, taking the example of Turkey, there was, at the time of the survey, a strong opposition to Erdogan's de-secularising policies. People opposing Erdogan are often strongly left, and see themselves as defending Kemalism, the legacy of the country's secularising moderniser Ataturk, which could be why left-wing political causes are so important to these people. We suggest that in Denmark and Finland on the other hand, these topics are not highly important to secular individuals specifically. 
PREPRINT

Table 7

Top ten most important worldviews per country with percentages of individuals mentioning responses in each category

\begin{tabular}{|c|c|c|c|c|c|c|c|c|c|}
\hline Australia & $\%$ & Brazil & $\%$ & Canada & $\%$ & Czech Republic & $\%$ & Denmark & $\%$ \\
\hline Science & 41 & Science & 35 & Science & 44 & Science & 26 & Science & 39 \\
\hline Critical Scepticism & 29 & Natural Laws & 18 & Humanism & 25 & Critical Scepticism & 21 & Humanism & 36 \\
\hline Humanism & 23 & Philosophical Materialism & 15 & Equality & 20 & Humanism & 20 & Natural Laws & 27 \\
\hline Natural Laws & 17 & Reject Superstition & 12 & Kindness \& Caring & 20 & Atheism & 15 & Critical Scepticism & 16 \\
\hline Secularism & 14 & Equality & 12 & Critical Scepticism & 16 & Equality & 12 & Kindness \& Caring & 16 \\
\hline Equality & 13 & Peace \& Collaboration & 12 & Natural Laws & 14 & Natural Laws & 11 & Equality & 11 \\
\hline Flourish & 12 & Secular Morality & 11 & Care for the Earth & 13 & Left-Wing Political Causes & 11 & Responsibility \& Free Will & 10 \\
\hline Antitheism & 11 & Responsibility \& Free Will & 10 & Peace \& Collaboration & 11 & Existent & 10 & Secularism & 9 \\
\hline Reject Superstition & 11 & Atheism & 9 & Responsibility \& Free Will & 10 & Philosophical Materialism & 8 & Philosophical Materialism & 9 \\
\hline Philosophical Materialism & 11 & Individualism \& Freedom & 9 & Unattainable Truth & 10 & Individualism \& Freedom & 8 & Individualism \& Freedom & 9 \\
\hline Finland & $\%$ & United Kingdom & $\%$ & Netherlands & $\%$ & Turkey & $\%$ & United States & $\%$ \\
\hline Science & 59 & Humanism & 34 & Science & 24 & Left-Wing Political Causes & 29 & Science & 39 \\
\hline Humanism & 37 & Kindness \& Caring & 26 & Humanism & 20 & Science & 21 & Humanism & 31 \\
\hline Natural Laws & 21 & Science & 23 & Critical Scepticism & 16 & Humanism & 21 & Critical Scepticism & 21 \\
\hline Care for the Earth & 18 & Equality & 19 & Care for the Earth & 16 & Critical Scepticism & 17 & Kindness \& Caring & 20 \\
\hline Critical Scepticism & 17 & Just One Life & 18 & Natural Laws & 12 & Atheism & 16 & Flourish & 19 \\
\hline Equality & 15 & Golden Rule & 17 & Peace \& Collaboration & 12 & Equality & 16 & Equality & 16 \\
\hline Antitheism & 12 & Care for the Earth & 17 & Left-Wing Political Causes & 10 & Kindness \& Caring & 14 & Golden Rule & 13 \\
\hline Atheism & 12 & Critical Scepticism & 16 & Kindness \& Caring & 10 & Care for the Earth & 14 & Care for the Earth & 13 \\
\hline Individualism \& Freedom & 12 & Peace \& Collaboration & 15 & Individualism \& Freedom & 10 & Natural Laws & 11 & Just One Life & 12 \\
\hline Philosophical Materialism & 11 & Natural Laws & 14 & Antitheism & 9 & Intuitive Morality & 9 & Atheism & 11 \\
\hline
\end{tabular}

Note. Countries ordered alphabetically; categories also present in global top ten are displayed in coloured font. 


\section{PREPRINT}

\section{Discussion}

This research project had three main aims: (1) to examine the content and range of secular (i.e., nonreligious non-theistic) beliefs and worldviews; (2) to investigate whether secular beliefs cluster together in ways similar to theoretical proposals; and (3) to explore how these different types of beliefs might vary across countries. To meet these aims, we designed a survey with a predetermined list of beliefs as well as an open-ended question asking participants about their most important secular beliefs and worldviews. Approximately one thousand non-religious non-theistic individuals were recruited from ten countries around the world ( $\sim 100$ participants from each country) to complete the survey. These countries included Australia, Brazil, Canada, Czech Republic, Denmark, Finland, the Netherlands, Turkey, United Kingdom, and the United States. The majority of these participants indicated to be atheists, followed by individuals who indicated to have 'no religion', followed by agnostics, humanists, and spiritual but not religious individuals, as well as indifferent individuals.

First, endorsements of prelisted beliefs were investigated, and it was found that they clustered together in three separate clusters: spiritual beliefs (e.g., belief in reincarnation, souls, karma, etc.), humanist beliefs (belief in nature, human ability and goodness, science), and science and logic beliefs (belief in science and logic or reason). These sets respectively represent the worldviews of spiritual but not religious individuals (Fuller, 2001; Lindeman et al., 2019), secular humanists (Lee, 2015), and intellectual atheist/agnostic individuals (Silver et al., 2014). On average, spiritual beliefs were not endorsed in this sample, which was unsurprising given a majority of atheists and minority of spiritual but not religious individuals in the participant distribution.

Next, the responses to the open-ended question about the participants' most important or meaningful worldviews, beliefs, or understandings of the world were examined. To code these responses, a bottom-up, data-driven method was used to develop a coding scheme. This resulted in a coding scheme with 51 categories within 11 supercategories (listed alphabetically): agency \& control, collaboration \& peace, equality \& kindness, morality, natural laws \& the here and now, nonreligiosity, reflection \& acceptance, science \& critical thinking, spirituality, truth, and other. These supercategories each fit within previously proposed theoretical worldview components (KoltkoRivera, 2004), such as axiology, teleology, epistemology, ontology/cosmology, and praxeology (Johnson et al., 2011; Taves et al., 2018), with the category non-religiosity fitting under both epistemology and ontology/cosmology. In other words, while having emerged from a data-driven rather than theory-driven approach, the supercategories are together able to answer the 'big questions' (Taves, 2020), including 'what is the good that we should strive for, what is good and evil' (axiology), 'what can we control, do we have free will' (teleology), 'what can we know, how do we know what is true, how should we reason' (epistemology), 'what exists, what is real; where do we come from and where are we going (incl. afterlife)' (ontology \& cosmology), and 'what actions should we take (in particular within the context of communities)' (praxeology). 


\section{PREPRINT}

In terms of the individual categories, the top ten categories that responses fell into, were: Science (mentioned in $35.1 \%$ of all responses), Humanism (25.5\%), Critical Scepticism (17.4\%), Natural Laws (15.6\%), Equality (14.0\%), Kindness \& Caring (13.6\%), Care for the Earth (11.5\%), Left-Wing Political Causes (10.1\%), Atheism (9.9\%), Individualism \& Freedom (9.8\%). Science was the top category for eight of the ten countries (second place for Turkey, and third place for United Kingdom). This is in line with previous research, which suggests that science is secular individuals' central epistemological worldview component: atheists and other secular people emphasise evidencebased, rational thought in their narratives (Hunsberger \& Altemeyer, 2006), unbelievers are more likely than the general population to perceive science as the 'only reliable path to knowledge' (Bullivant et al., 2019), effects which are especially pronounced for atheists in the United States (Pasquale, 2009). Science can also feature as an ontological/cosmological feature however: it can allow atheists to feel part of something greater than themselves (Caldwell-Harris et al., 2011; Haimila, 2020) and allow one to find 'one's place in the universe' (Lee, 2015, p. 146). Thus, the identification with science may provide a sense of meaning for secular individuals, and can help find meaning in the world (Bullivant et al., 2019; Farias et al., 2013; Haimila, 2020).

Humanism, the category mentioned second most often, is interesting in that it overlaps with a high appreciation for science and scientific method (indeed, secular individuals have been found to often rely on a secular-scientific and humanist belief system in certain samples; Smith, 2017), but also places much value on humans and their goodness and ability (Lee, 2015). This extends to praxeology, whereby actively contemplating - and even seeking to change - societal structures and values is important (Kontala, 2016; Taylor, 2007). Critical scepticism is again similar to the science category, but it emphasises epistemology and may include a more critical view on the scientific method, thus allowing more uncertainty (Smith \& Halligan, 2021) and for more critical or logical thought (Pasquale, 2009). The natural laws category reflect the previously researched secular beliefs that humans are a natural creature (Smith \& Halligan, 2021), like other animals (Zuckerman, 2020), and consist wholly of matter (Wilkinson \& Coleman, 2010), a clear ontology/cosmology worldview component.

Notably, in the present research the participants were asked about their "worldviews, beliefs, or understandings of the world that are particularly meaningful", which was phrased this way to get at the participants' worldview or 'existential' beliefs (Lee, 2015). Other research has indicated however that, when asked 'what provides [the participants] meaning' (note the slightly different angle), the answer is generally first and foremost 'family' (Bullivant et al., 2019; Pasquale, 2009), followed by freedom or friendship, equality or compassion (Bullivant et al., 2019) or helping or caring for others, and on fifth and sixth place 'people, social relations in general' and 'friends, friendship' (Pasquale, 2009). These responses did appear in the current research as well (family, friends, and community were coded under the category 'Connection', supercategory 'Collaboration \& peace'), but were not a highly frequent response, although the supercategory Equality and Kindness \& Caring did occur in the 


\section{PREPRINT}

top ten (fifth and sixth place, respectively). These discrepancies may be the result of the question formulation or sample recruitment, among other things.

A principal components analysis on the top ten most mentioned categories (across countries) demonstrated further patterns: equality, left-wing political causes, individualism \& freedom and humanism all loaded onto a factor which we called 'left-wing humanist responses'; science and critical scepticism loaded onto a factor which we called 'scientific sceptic responses', and care for the earth, kindness \& caring, and natural laws loaded onto a factor we called 'environmental caring responses'. Atheism did not uniquely load onto a single factor. We suggest that this may have the same underlying reason as non-religiosity as a category fitting into multiple worldview components: secular individuals (in particular a sample comprised of mostly atheists as the current one) may dissociate themselves from religion in several ways, such as denying religion as a way of knowing things (epistemology) and as a way of understanding where we come from and what is real (cosmology and ontology).

While the predetermined belief sets or patterns did not always correlate significantly with these worldview patterns, it was telling that three similar sets were found across both: predetermined spiritual beliefs reflecting cosmology and ontology components and environmental caring responses reflected cosmology and praxeology, predetermined humanist beliefs reflecting praxeology, epistemology and axiology and left-wing humanist responses reflecting praxeology, and predetermined science and logic beliefs reflecting epistemology and ontology and scientific sceptic responses reflecting epistemology. Thus this research demonstrates several of the ways in which secular individuals fill in these 'big questions' that worldviews address. Interestingly, in this sense, future research may consider running a similar version of this survey for religious individuals. While theologies may prescribe certain answers to the big questions, there is space for individual variation as well as between theological traditions (even of the same religion).

While we do not have comparative data, it is worth speculating how much secular worldviews may differ from those of religious people in the same countries. This is an enormous question and we can only briefly consider it here. On the one hand, some recent evidence suggests that religious and non-religious individuals overlap greatly in their reported values (Bullivant et al., 2019), and historians have noted that secular humanism has Christian roots (e.g., Holland, 2019; Taylor, 2007), something that likely entails common core values (equality and compassion, for instance). On the other hand, some studies suggest underlying differences in moral cognition between religious and secular individuals, something that would likely impact their worldviews (Haidt \& Graham, 2007; Lanman, 2009). More fundamentally, comparisons are complicated by the fact that there is no clean binary division between religious and secular people (highly secularised European societies, for instance, are noteworthy for having large 'fuzzy' populations who are neither explicitly religious nor non-religious; Voas, 2009). 


\section{PREPRINT}

The cross-cultural variation in secular beliefs and worldviews in the ten countries was examined. A question of interest therein is whether differences in societal values are reflected in country-level differences in the contents of secular worldviews. For instance, left-wing politics is noticeably more salient in the Turkish sample, which probably reflects a rejection of Erdogan's conservative Islamism and the threat it poses to the secular state. However, this stands out as an exception, with our data suggest that 'unbelieving' worldviews are broadly similar in the countries studied: despite the geographical, cultural, and socioeconomic differences between these countries, the lists of top ten most frequently named categories of each country showed many overlaps. It could be the case that secular worldviews really do not differ that much country to country. The growth of the non-religious population in recent decades has coincided with an amplification in the globalisation of ideas thanks to developments in communications technology, which may help to transplant new worldviews from place to place with a high degree of fidelity (e.g., Acerbi, 2019), and some observers suggest the internet has been highly influential in spreading and sustaining atheist worldviews (Smith $\&$ Cimino, 2012). We must be very cautious about making such inferences though.

Another reason for the similarities might be that despite the variety in the countries, most of the sampled countries are still western or W.E.I.R.D. (Western Industrialized Educated Rich Democratic; Henrich et al., 2010). The countries were chosen on the basis of a combined desire for cross-cultural variety and presence of collaborative expertise in belief and/or unbelief. We suggest that future research may go further beyond this selection of countries, in increasing cultural distance (Muthukrishna et al., 2020). For example, it may be particularly interesting to investigate secular beliefs and worldviews in countries where religion is considered important for the majority of the population. The present sample contained three such countries (out of ten): Brazil, Turkey, and the United States. An advantage for such future research may be that rather than using another openended survey approach, a questionnaire or list of secular beliefs may be based on the coding categories resulting from the present dataset (and overarching supercategories or worldview components). Future research projects utilising such a survey would then also have the advantage of going beyond a limitation of one hundred participants per country, which was a necessary limitation given the time and other resources it took to translate and code the responses for this open-ended survey.

If there is funding for it, future research may also consider targeting representative samples (e.g., Bullivant et al., 2019; Schnell \& Keenan, 2011). Here, recruitment was online without participant reimbursement (though several raffles were organised to stimulate participation), and participants were mostly recruited through online groups (Facebook pages or newsletters). This means that many of the secular individuals that were reached were involved in digital media and had an interest in, or were part of, a secular organisation (like much of the previous research, e.g., Kontala, 2016; Langston et al., 2020; Pasquale, 2009; Smith, 2017; Smith \& Halligan, 2021). This may indicate that religious non-belief is an important component of their social identities, and it may be 


\section{PREPRINT}

that secular individuals in the general population, outside these digital environments, are more indifferent to religion and less cross-culturally similar than the current sample, which warrants exploring.

While this research did not aim to cluster secular individuals, and instead focused on exploring potential clusters of secular beliefs, overlaps with previously suggested and demonstrated non-religious groupings (Lee, 2015; Lindeman et al., 2019; Manning, 2015; Silver et al., 2014) were noted. Previous data-driven groupings have been based on qualitative research (Lee, 2015; Manning, 2015) or quantitative research (Lindeman et al., 2019), or combination of qualitative and quantitative research (Silver et al., 2014). These groupings included analytical atheists, spiritual but not religious and uncertain nonbelievers (Lindeman et al., 2019), unchurched believers, spiritual seekers, philosophical secularists and indifferent (Manning, 2015), humanists, agnostics, theists and subjectivists, and anti-existentialists (Lee, 2015), and academic atheists, activist atheist/agnostics, seeker agnostics, antitheists, non-theists, and ritual atheists (Silver et al., 2014). Throughout these groupings, as well as in the present research to some extent, three main lines become evident: individuals who are strongly confident about the scientific method, individuals with non-religious spiritual beliefs, and those who are uncertain, agnostic or indifferent. Strong anti-religious sentiments are not consistently present in the classifications, and, while they occurred in the present data as well, do not have the overtone.

Non-religious affiliation labels are a contested topic for researchers (Bullivant \& Ruse, 2013; Lee, 2015; Lee \& Bullivant, 2016) and secular individuals alike: a recurring lack of established 'worldview programmes' for each of the non-religious affiliations ${ }^{2}$ as one might see for, broadly speaking, the Catholic church or Pentecostalism, means that the individuals need to gauge themselves which labels is most befitting to them, even if the labels are not particularly specific ("no religion") or if a restricted range is given (e.g., "humanist" or "rationalist" may be lacking from commonly presented options). Bullivant et al. (2012) for example had a question categorising each 'unbeliever' participant as either atheist ("I don't believe in God") or agnostic ("I don't know whether there is a God, and I don't believe there is any way to find out"), but these individuals were still distributed over 12 different labels which they could pick themselves (i.e., atheist, non-religious, rationalist, free thinker, spiritual but not religious, humanist, 'religious label', agnostic, seeker, sceptic, secular, or other). It should be noted that our exclusion criteria - non-religious non-theistic individuals - may have resulted in an overrepresentation of atheists, and underrepresentation of agnostics or people who do not believe in God but still consider themselves religiously affiliated in some way. However, it was the aim of this study to specifically look at non-religious non-theistic individuals, and we were interested in an open-ended exploration of beliefs and worldviews rather than group affiliation labels,

\footnotetext{
${ }^{2}$ There are exceptions for certain secular organisations which make explicit their overarching worldview, such as for example the Rationalist Society of Australia, https://rationalist.com.au/about/about-us/.
} 


\section{PREPRINT}

which may conceal diversity and complexity (Pasquale, 2009), but future research may extend this to larger groups of secular individuals with less stringent criteria.

Finally, it is worth pausing to consider the implications of our findings for atheists and other non-religious individuals themselves. Cross-cultural evidence suggests that those who do not believe in a God or gods are frequently the targets of prejudice, and that this is based on the implicit assumption that atheists must be amoral nihilists (Gervais et al., 2017). The present research clearly demonstrates that 'unbelievers' by no means 'believe in nothing'. They have principled worldviews which encompass many highly prosocial components, such as the importance of equality and compassion. Hopefully, worldview research and the insights it provides can start making changes to these negative attitudes.

\section{Conclusions}

An increase in non-religious individuals around the world and a concurrent increase in secular organisations ask for a better understanding of secular beliefs and worldviews beyond a simple lack of religious beliefs. This open-ended data-driven exploratory research has demonstrated that there is a range of secular beliefs which answer the big questions about life, broadly in line with previous theoretical work on beliefs and worldviews. These beliefs were found to cluster together in scientific worldviews, humanist worldviews, and caring nature-focused worldviews. This research is a timely exploration of beliefs and worldviews of the growing population of secular individuals around the world.

\section{Acknowledgments}

A special thanks to Claire Berlyn of the Understanding Unbelief team for all her assistance throughout the project, administrative and otherwise. Thanks also to Coventry University research assistants Aleksandra Tkaczyk, Alexandra Pap, and Maria Vasconcelos Tavares Monteiro for their assistance with the coding of the worldview answers of the United Kingdom, Canada, and Australia respectively, and Anne Lundahl Mauritsen and Gillian Kobia for their Danish and Dutch translations and assistance with coding.

\section{Funding}

This research was funded by an Understanding Unbelief RFP2 Early Career Award awarded to VVM; BGP and TB acknowledge support from the Aarhus University Research Foundation; RH was supported by a research grant from the Finnish Cultural Foundation (grant number: 00180271). 


\section{PREPRINT}

\section{References}

Acerbi, A. (2019). Cultural Evolution in the Digital Age. Oxford University Press.

Beit-Hallahmi, B. (2007). Atheists: A psychological profile. In M. Martin (Ed.), The Cambridge Companion to Atheism (pp. 300-317). Cambridge University Press. https://doi.org/10.1017/CCOL0521842700.019

Brown, C. G. (2017). Becoming atheist: Humanism and the secular West. Bloomsbury Publishing.

Bullivant, S., Farias, M., Lanman, J., \& Lee, L. (2019). Understanding Unbelief: Atheists and agnostics around the world. Research report.

Bullivant, S., \& Lee, L. (2012). Interdisciplinary studies of non-religion and secularity: The state of the union. Journal of Contemporary Religion, 27(1), 19-27. https://doi.org/10.1080/13537903.2012.642707

Bullivant, S., \& Ruse, M. (2013). The Oxford handbook of atheism. Oxford University Press.

Caldwell-Harris, C. L., Wilson, A. L., LoTempio, E., \& Beit-Hallahmi, B. (2011). Exploring the atheist personality: Well-being, awe, and magical thinking in atheists, Buddhists, and Christians. Mental Health, Religion \& Culture, 14(7), 659-672. https://doi.org/10.1080/13674676.2010.509847

Coleman, T. J. I., Messick, K., \& van Mulukom, V. (forthcoming). Atheism: A New Evolutionary Perspective on Non-Belief. In Y. Lior \& J. E. Lane (Eds.), The Routledge Handbook of Evolutionary Approaches to Religion. Routledge.

Droogers, A. F. (2014). The world of worldviews. In A. F. Droogers \& A. van Harskamp (Eds.), Methods for the Study of Religious Change (pp. 17-42). Equinox.

Engelke, M. (2014). Christianity and the anthropology of secular humanism. Current Anthropology, 55(S10), S292-S301. https://doi.org/10.1086/677738

Farias, M. (2013). The psychology of atheism. In S. Bullivant \& M. Ruse (Eds.), The Oxford Handbook of Atheism (pp. 468-482). Oxford University Press.

Farias, M., Newheiser, A.-K., Kahane, G., \& de Toledo, Z. (2013). Scientific faith: Belief in science increases in the face of stress and existential anxiety. Journal of Experimental Social Psychology, 49(6), 1210-1213. https://doi.org/10.1016/j.jesp.2013.05.008

Fuller, R. C. (2001). Spiritual, but not religious: Understanding unchurched America. Oxford University Press. 


\section{PREPRINT}

Gervais, W. M., Xygalatas, D., McKay, R. T., Van Elk, M., Buchtel, E. E., Aveyard, M., Schiavone, S. R., Dar-Nimrod, I., Svedholm-Häkkinen, A. M., \& Riekki, T. (2017). Global evidence of extreme intuitive moral prejudice against atheists. Nature Human Behaviour, 1(8), 0151. https://doi.org/10.1038/s41562-017-0151

Haidt, J., \& Graham, J. (2007). When morality opposes justice: Conservatives have moral intuitions that liberals may not recognize. Social Justice Research, 20(1), 98-116. https://doi.org/10.1007/s11211-007-0034-z

Haimila, R. (2020). Does a Science-Oriented Worldview Entail Unbelief?: Meaning, Morality, and Continuity from Scientific Research in Self-Reports of Finnish Unbelievers and Believers. Secular Studies, 2(2), 83-116. https://doi.org/10.1163/25892525-bja10006

Haimila, R., \& Muraja, E. (2021). A sense of continuity in mortality? Exploring science-oriented Finns' views on afterdeath. OMEGA - Journal of Death and Dying https://doi.org/10.1177/00302228211038820

Heine, S. J., Proulx, T., \& Vohs, K. D. (2006). The meaning maintenance model: On the coherence of social motivations. Personality and social psychology review, 10(2), 88-110. https://doi.org/10.1207/s15327957pspr1002___

Henrich, J., Heine, S. J., \& Norenzayan, A. (2010). The weirdest people in the world? Behavioral and brain sciences, 33(2-3), 61-83. https://doi.org/10.1017/S0140525X0999152X

Holland, T. (2019). Dominion: The Making of the Western Mind. Brown Book Group.

Hout, M., \& Fischer, C. S. (2014). Explaining Why More Americans have No Religious Preference: Political Backlash and Generational Succession, 1987-2012. Sociological Science, 1. https://doi.org/10.15195/v1.a24

Hunsberger, B. E., \& Altemeyer, B. (2006). Atheists: A groundbreaking study of America's nonbelievers. Prometheus Books.

Inglehart, R. (2021). Religion's sudden decline: what's causing it, and what comes next? Oxford University Press, USA.

Inglehart, R., \& Welzel, C. (2005). Modernization, cultural change, and democracy: The human development sequence. Cambridge University Press.

Johnson, K. A., Hill, E. D., \& Cohen, A. B. (2011). Integrating the study of culture and religion: Toward a psychology of worldview. Social and Personality Psychology Compass, 5(3), 137 152. https://doi.org/10.1111/j.1751-9004.2010.00339.x 


\section{PREPRINT}

Jonas, E., McGregor, I., Klackl, J., Agroskin, D., Fritsche, I., Holbrook, C., Nash, K., Proulx, T., \& Quirin, M. (2014). Threat and defense: From anxiety to approach. In Advances in experimental social psychology (Vol. 49, pp. 219-286). Elsevier.

Koltko-Rivera, M. E. (2004). The psychology of worldviews. Review of general psychology, 8(1), 358. https://doi.org/10.1037/1089-2680.8.1.3

Kontala, J. (2016). Emerging non-religious worldview prototypes: a faith Q-sort-study on Finnish group-affiliates Åbo Akademi University].

Langston, J., Speed, D., \& Coleman, T. J. I. (2020). Predicting age of atheism: credibility enhancing displays and religious importance, choice, and conflict in family of upbringing. Religion, Brain \& Behavior, 10(1), 49-67. https://doi.org/10.1080/2153599X.2018.1502678

Lanman, J. (2009). A Secular Mind: Towards a Cognitive Anthropology of Atheism [Unpublished DPhil Thesis, University of Oxford].

Lee, L. (2015). Recognizing the Non-Religious: Reimagining the Secular. Oxford University Press.

Lee, L., \& Bullivant, S. (2016). Oxford Dictionary of Atheism. Oxford University Press.

Lindeman, M., van Elk, M., Lipsanen, J., Marin, P., \& Schjoedt, U. (2019). Religious unbelief in three western European countries: Identifying and characterizing unbeliever types using latent class analysis. The International Journal for the Psychology of Religion, 29(3), 184-203. https://doi.org/10.1080/10508619.2019.1591140

Manning, C. J. (2015). Losing our religion. New York University Press.

Mauritsen, A. L., \& van Mulukom, V. (forthcoming). Never mind the Gods: Explaining Unbelief and Non-religion. In B. G. Purzycki \& T. Bendixen (Eds.), The Minds of Gods: A CrossDisciplinary Survey Bloomsbury.

Muthukrishna, M., Bell, A., Henrich, J., Curtin, C., Gedranovich, A., McInerney, J., \& Thue, B. (2020). Beyond WEIRD psychology: Measuring and mapping scales of cultural and psychological distance.

Pasquale, F. L. (2009). A portrait of secular group affiliates. In P. Zuckerman (Ed.), Atheism and Secularity: Global Expressions (pp. 43-88). Praeger.

Schnell, T., \& Keenan, W. J. (2011). Meaning-making in an atheist world. Archive for the Psychology of Religion, 33(1), 55-78. https://doi.org/10.1163/157361211X564611 


\section{PREPRINT}

Silver, C. F., Coleman, T. J. I., Hood., R. W. J., \& Holcombe, J. M. (2014). The six types of nonbelief: a qualitative and quantitative study of type and narrative. Mental Health, Religion \& Culture, 17(10), 990-1001. https://doi.org/10.1080/13674676.2014.987743

Smith, C., \& Cimino, R. (2012). Atheisms unbound: The role of the new media in the formation of a secularist identity. Secularism and Nonreligion, 1(1), 17-31. https://doi.org/10.5334/snr.ab

Smith, J. M. (2017). Can the secular be the object of belief and belonging? The Sunday assembly. Qualitative Sociology, 40(1), 83-109. https://doi.org/10.1007/s11133-016-9350-7

Smith, J. M., \& Halligan, C. L. (2021). Making Meaning without a Maker: Secular Consciousness through Narrative and Cultural Practice. Sociology of Religion, 82(1), 85-110. https://doi.org/10.1093/socrel/sraa016

Taves, A. (2020). From religious studies to worldview studies. Religion, 50(1), 137-147. https://doi.org/10.1080/0048721X.2019.1681124

Taves, A., Asprem, E., \& Ihm, E. (2018). Psychology, meaning making, and the study of worldviews: Beyond religion and non-religion. Psychology of Religion and Spirituality, 10(3), 207-217. https://doi.org/10.1037/rel0000201

Taylor, C. (2007). A secular age. Harvard University Press.

Turner, J. (1985). Without God, without creed: The origins of unbelief in America. Johns Hopkins University Press.

Voas, D. (2009). The rise and fall of fuzzy fidelity in Europe. European Sociological Review, 25(2), 155-168. https://doi.org/10.1093/esr/jen044

Wilkinson, P. J., \& Coleman, P. G. (2010). Strong beliefs and coping in old age: A case-based comparison of atheism and religious faith. Ageing \& Society, 30(2), 337-361. https://doi.org/10.1017/S0144686X09990353

Zuckerman, P. (2020). Society without God: What the Least Religious Nations Can Tell Us about Contentment. New York University Press. https://doi.org/10.18574/9781479851119 
PREPRINT

What do non-religious non-believers believe in? Secular worldviews around the world

Supplementary Materials 


\section{SM.1 Descriptive statistics}

\section{Table SM1.1}

Country-level average demographic variables

\begin{tabular}{|c|c|c|c|c|c|c|c|c|c|c|}
\hline & AUS & BRA & CAN & CZE & DNK & FIN & GBR & NLD & TUR & USA \\
\hline $\begin{array}{l}\text { GDP in USD \$ million } \\
\text { (2018) }\end{array}$ & 1.43 & 1.87 & 1.71 & 0.24 & 0.35 & 0.28 & 2.83 & 0.91 & 0.77 & 20.49 \\
\hline $\begin{array}{l}\text { GDP per capita in } \\
\text { USD\$ (2019) }\end{array}$ & 62,765 & 10,693 & 51,015 & 25,910 & 66,946 & 54,975 & 44,759 & 58,184 & 11,527 & 65,064 \\
\hline Gini index & 34.7 & 51.3 & 34 & 25.9 & 28.5 & 26.8 & 34.1 & 28.6 & 41.2 & 41 \\
\hline Religion important (\%) & 32 & 87 & 42 & 21 & 19 & 28 & 27 & 33 & 82 & 65 \\
\hline
\end{tabular}

\section{Post-hoc comparisons of demographic variables between the countries}

Age. Bonferroni-corrected post-hoc comparisons demonstrated the significant difference in age between the countries to be driven by BRA participants being significantly younger on average than participants from DNK, GBR, CAN, AUS, and older than participants from CZE ( $p$-values < .02). Indeed, the CZE participants were significantly younger than all other participants except TUR ( $p$ values <.02), and TUR participants in turn were younger than all other countries except BRA ( $p=$ .71 ), while AUS participants were significantly older than all other participants ( $p$-values $<.001$ ).

Years of education. Bonferroni post-hoc comparisons indicated that this difference was driven by participants from FIN and NLD having more years of education than participants from TUR ( $p=007$ and $p=.02$, respectively), with no other significant differences.

\footnotetext{
${ }^{3}$ Gallup, 2008. State of the World: 2008 Annual Report. New York: Gallup Press.

${ }^{4}$ Gallup, 2009 .Gallup world poll. Online database at http://www.gallup.com/consulting/worldpoll/24046/About.aspx

5 https://data.worldbank.org/indicator/SI.POV.GINI
} 


\section{PREPRINT}

\section{Post-hoc comparisons of demographic variables between the countries (cont'd)}

Self-reported spirituality. Bonferroni-corrected post-hoc comparisons demonstrated that this effect was driven by FIN $^{6}$ and TUR participants indicating a significantly higher spirituality than participants in the other countries ( $p$-values $<.02)$, except for compared to each other $(p>.99)$ and NLD ( $p$-values > .99). NLD participants were significantly more spiritual than BRA, DNK, CAN, and AUS ( $p$-values <. 01), with no other significant differences.

\section{Table SM1.2}

Percentages of non-religious affiliations for each of the countries

\begin{tabular}{lccccccccccc}
\hline Denomination & AUS & BRA & CAN & CZE & DNK & FIN & GBR & NLD & TUR & USA & $a v g$ \\
\hline Atheist & 85.0 & 82.0 & 77.1 & 55.0 & 63.0 & 58.0 & 71.0 & 52.0 & 65.0 & 71.0 & 67.9 \\
No religion & 9.0 & 2.0 & 4.2 & 20.0 & 11.0 & 18.0 & 10.0 & 17.0 & 13.0 & 10.0 & 11.4 \\
Agnostic & 1.0 & 10.0 & 7.3 & 11.0 & 10.0 & 7.0 & 5.0 & 6.0 & 7.0 & 6.0 & 7.0 \\
SBNR & 1.0 & 4.0 & 4.2 & 4.0 & 5.0 & 6.0 & 3.0 & 14.0 & 3.0 & 1.0 & 4.5 \\
Indifferent & 0.0 & 2.0 & 1.0 & 4.0 & 1.0 & 7.0 & 2.0 & 6.0 & 9.0 & 4.0 & 3.6 \\
Other & 2.0 & 0.0 & 4.2 & 6.0 & 7.0 & 4.0 & 2.0 & 4.0 & 3.0 & 6.0 & 3.5 \\
Humanist & 2.0 & 0.0 & 2.1 & 0.0 & 3.0 & 0.0 & 7.0 & 1.0 & 0.0 & 5.0 & 2.0 \\
\hline
\end{tabular}

Note. SBNR=Spiritual but not religious.

\footnotetext{
${ }^{6}$ We note this may be an artefact of our translation: In Finnish, there are two possible (wide-spread) translations for "spirituality", one of which refers to the more churched spirituality (hengellisyys) and another that has a less religious connotation (henkisyys). Of these, the latter was applied (see Kontala, 2016, p. 191).
} 


\section{SM.2 List of sources for participant recruitment}

\section{General}

Facebook groups

- Secular Society (https://www.facebook.com/groups/670714003090302/)

- Atheist, Agnostic, and Non-Religious (https://www.facebook.com/groups/OAANR/)

- World Secular Humanist Movement (https://www.facebook.com/groups/332377947232004/)

Reddit: https://www.reddit.com/

- $\mathrm{r} / \mathrm{humanism} /$

- r/atheism/

- $\mathrm{r} / \mathrm{secularism} /$

- $\mathrm{r} /$ SecularHumanism/

- r/agnostic/

- r/agnosticism/

- r/skeptic/

Other

- Richard Dawkins Foundation for Science and Reason

(https://www.facebook.com/RichardDawkinsFoundation; https://twitter.com/rdfrs)

- Center for Inquiry (https://centerforinquiry.org/)

- The Friendly Atheist, Hemant Mehta (https://friendlyatheist.patheos.com/)

\section{Australia}

See General, and:

- Rationalist Society of Australia (e-mail newsletter)

\section{Brazil}

- Associação Brasileira de Ateus e Agnósticos / Brazilian Association of Atheists and Agnosticis (https://www.facebook.com/atea.org.br and e-mail newsletter)

- Universo Racionalista / Rationalist Universe (https://www.facebook.com/groups/universoracionalista)

\section{Canada}

See General, and:

- Canadian Secular Alliance (e-mail newsletter)

- Winnipeg Skeptics Discussion Group (https://www.facebook.com/groups/winnipegskeptics/)

\section{Czech Republic}

Facebook pages:

- Vědátor / Scienator (https://www.facebook.com/VedatorCZ/)

- Ateisté ČR / Atheists CZ* (https://www.facebook.com/ateiste/)

Facebook groups:

- Český klub skeptiků Sisyfos / Czech Skeptic Club Sisyfos (https://www.facebook.com/cesky.klub.skeptiku.SISYFOS/)

- Ateisté / Atheist* (https://www.facebook.com/groups/ateiste/) 


\section{PREPRINT}

- Nekomerční esoterika / Noncommercial esotericism (https://www.facebook.com/groups/nekomercni.esoterika/)

○ Very few people from here, if anybody at all, participated.

*Both maintained by Občanské sdružení ateisti̊ v $\check{C} R$ (Association of Czech Atheists) founded at the end of the 2000 .

\section{Denmark}

Facebook:

- Ateistisk Selskab - Debatgruppe / Atheistic Society - Debating Forum [unofficial debating forum] (https://www.facebook.com/groups/ateistiskselskab/)

Other:

- Ateistisk Selskab [Atheistic Society]'s official members mailing list

\section{Finland}

Facebook:

- Suomen Humanistiliitto / Finnish Humanist Association (https://www.facebook.com/humanistiliitto/)

- Sunday Assembly Helsinki / Sunday Assembly Helsinki Facebook group (there is no Sunday Assembly in Helsinki, but the group has previously discussed founding a local section) (https://www.facebook.com/groups/1507052702951128/)

- Vapaa-ajattelijain Liitto / Union of Freethinkers of Finland (https://www.facebook.com/groups/vapariliitto/)

- Skepsis ry / Finnish Association of Skeptics (https://www.facebook.com/groups/skepsisry/)

Twitter:

- Vapaa-ajattelijain Liitto / Union of Freethinkers of Finland (https://twitter.com/VapariLiitto)

- Helsingin seudun vapaa-ajattelijat ry / Freethinkers Helsinki Area Association (https://twitter.com/HelVaparit)

Other:

- Suomen Ateistiyhdistys / Finnish Atheist Association (the invitation was also sent to this very small organization, not present in social media).

All the above organizations may have sent the invitation also to their email lists, if these are included in online sources. For example, the Union of Freethinkers have local sections (independent associations) in different parts of Finland, and they may have shared the invitation that was sent in their Facebook groups and mailing lists.

\section{Great Britain}

See General, and:

- Secularism org UK (https://www.reddit.com/r/SecularismOrgUK/)

- Atheism UK (https://www.facebook.com/groups/atheismUKclosedgroup/)

- Atheism United of England: A Branch of Atheism United Headquarters (https://www.facebook.com/groups/RotA2014/)

\section{Netherlands}

Twitter:

- Atheistisch Verbond / Atheist Alliance (https://twitter.com/AtheistischVerb) 


\section{PREPRINT}

- Atheïstisch Seculiere Partij / Atheistic Secular Party (https://twitter.com/ASPDeventer)

- Positief Atheïsme / Positive Atheism (https://twitter.com/positiefatheism)

- Universiteit van de Humanistiek / University of Humanistic Studies (https://twitter.com/uvh)

Facebook groups:

- Filosofie en spiritualiteit / Philosophy and spirituality (https://www.facebook.com/groups/filosofieenspiritualiteit/)

- Filosofie, seculiere spiritualiteit \& levenskunst / Philosophy, secular spirituality \& the art of living (https://www.facebook.com/groups/293678130745900/)

- Duurzaam minimaliseren - verklein je ecologische voetafdruk / Minimalising sustainably reduce your ecological footprint (https://www.facebook.com/groups/1385593141454921/)

- Duurzaam leven met kinderen / Living sustainably with children (https://www.facebook.com/groups/101527510414114/)

- Groep Duurzaam Nederland / Group Sustainable Netherlands (https://www.facebook.com/groups/425441314470743/)

- Duurzame mannen en vrouwen / Sustainable men and women (https://www.facebook.com/groups/Duurzamemannenenvrouwen/)

\section{Turkey}

Facebook:

- Ateizm Derneği / The Atheism Association ( https://www.facebook.com/ateizmdernegi/ )

- Free-Thinking Movement of Turkey (https://www.facebook.com/Ozgur.Dusunce.Hareketi/)

- Research on Belief (https://www.facebook.com/Rbelief/)

\section{United States}

See General. 


\section{PREPRINT}

\section{SM.3 Predetermined lists of beliefs}

\section{Table SM3.1}

Average scores for clusters of the predetermined belief sets (spiritual beliefs, humanist beliefs, and science \& logic beliefs) for each of the countries

\begin{tabular}{llll}
\hline Country & $\begin{array}{l}\text { Spiritual } \\
\text { beliefs }\end{array}$ & $\begin{array}{l}\text { Humanist } \\
\text { beliefs }\end{array}$ & $\begin{array}{l}\text { Science \& } \\
\text { logic beliefs }\end{array}$ \\
\hline Australia & $-1.61(0.50)$ & $1.20(0.53)$ & $1.88(0.31)$ \\
Brazil & $-1.50(0.59)$ & $1.10(0.53)$ & $1.79(0.43)$ \\
Canada & $-1.53(0.59)$ & $1.20(0.51)$ & $1.85(0.35)$ \\
Czech & $-1.39(0.61)$ & $1.08(0.49)$ & $1.74(0.49)$ \\
Denmark & $-1.48(0.61)$ & $1.07(0.54)$ & $1.66(0.65)$ \\
Finland & $-1.58(0.56)$ & $0.97(0.40)$ & $1.77(0.53)$ \\
Netherlands & $-1.14(0.86)$ & $1.07(0.58)$ & $1.44(0.79)$ \\
Turkey & $-1.12(0.60)$ & $1.29(0.51)$ & $1.74(0.54)$ \\
United Kingdom & $-1.49(0.59)$ & $1.24(0.47)$ & $1.76(0.48)$ \\
United States & $-1.45(0.55)$ & $1.31(0.46)$ & $1.82(0.39)$ \\
\hline grand mean & $-1.43(0.63)$ & $1.15(0.51)$ & $1.74(0.53)$ \\
\hline
\end{tabular}

Note. Likert scale options ranged from -2 to 2: "I definitely do not hold this belief/view" (-2), "I do not hold this belief/view" (-1), "Neutral (0), "I hold this belief/view" (1) and "I definitely hold this belief/view" (2). 


\section{SM.4 Coding categories and supercategories}

\section{Table SM4.1}

Overview of all supercategories and categories of the dataset with first labels, examples, occurrence in participant responses (number and percentage)

\begin{tabular}{|c|c|c|c|c|c|}
\hline Category (label) & Short description & $\begin{array}{l}\text { Original category } \\
\text { labels }\end{array}$ & Example & Nr. & $\%$ \\
\hline \multicolumn{6}{|l|}{ Agency \& control } \\
\hline $\begin{array}{l}\text { Individualism \& } \\
\text { Freedom } \\
\text { IndivFreedom }\end{array}$ & $\begin{array}{l}\text { This category encompasses responses that emphasise } \\
\text { the importance of individual liberty, and/or advocate } \\
\text { resisting the imposition of excess constraints on } \\
\text { behaviour. Incl. "freedom of speech". }\end{array}$ & $\begin{array}{ll}\text { - } & \text { Freedom/Individua } \\
\text { lism (live and let } \\
\text { live) } \\
\text { - } & \text { Individualism } \\
\text { - } & \text { Libertarianism }\end{array}$ & $\begin{array}{l}\text { "Social liberty, human rights, freedom } \\
\text { of expression and belief. The right to } \\
\text { privacy." } \\
\text { "I believe }[\ldots] \text { that all people have the } \\
\text { right to live as they choose as long as } \\
\text { in doing so they are not knowingly } \\
\text { hurting others." }\end{array}$ & 98 & $9.8 \%$ \\
\hline $\begin{array}{l}\text { Karma \& Purpose } \\
\text { KarmaPurp }\end{array}$ & $\begin{array}{l}\text { This category encompasses responses that are based } \\
\text { on the notion that people get what they deserve due } \\
\text { to some underlying force or metaphysical principle, }\end{array}$ & $\begin{array}{l}\text { - Karma / 'what goes } \\
\text { around comes } \\
\text { around' }\end{array}$ & $\begin{array}{l}\text { "I believe that what goes around comes } \\
\text { around." }\end{array}$ & 19 & $1.9 \%$ \\
\hline
\end{tabular}


or that all things can be understood to have happened 'for a reason' (other than complex chains of prior physical events).

Psychology

Psych

Random

Responsibility and free will

ResponsFreeWill
Answers which reflect a belief in psychology, neuroscience, therapy, psychoanalysis, and other mental health concepts, and/or which draw attention to the material basis of the mind, including those responses which describe the neurochemical basis of mental illness.

This category encompasses responses that are the opposite of the Karma \& Purpose category: events in the world very often are random, happen by chance, and do not relate to the moral character of the person to whom they happen.

is category encompasses responses that emphasise personal control over behaviour and/or responsibility for one's actions.
- Purpose: Everything

happens for a reason

- Consciousness/cog nition: materialist

view are emergent properties of a physical brain.’”

(neuroscience,

functionalism, etc)

- NeuroDeterm

- Determinism

- OppositeKarma/'Sh it happens' (bad things happen to good people)

- Randomn/Chance/ Nihilist

- Pragmatism

- Pragm/AreWhatW eDo/Actions/Respo

nsible

- Free Will

"Things happen for a reason."

"The self is a neurological phenomenon."

"Psychology. Therapy." the random interaction of various physical systems."

"I believe in the randomness of life."

"We are responsible for our own actions."

"We are what we do."
"There are many events that don't have a deeper cause or meaning other than

"Shit happens, life is unfair, and it is up to us alone to try to bring some justice to this world."

"I believe we have free will."

\section{Collaboration \& peace}

\begin{tabular}{|c|c|c|c|c|c|}
\hline $\begin{array}{l}\text { Aggregate } \\
\text { flourishing }\end{array}$ & $\begin{array}{l}\text { This category encompasses responses that espouse a } \\
\text { utilitarian moral perspective (do minimal harm, }\end{array}$ & $\begin{array}{ll}\text { - } & \text { Moral Progress } \\
\text { - } & \text { Improve general }\end{array}$ & $\begin{array}{l}\text { "We have to act in ways that improve } \\
\text { life for everyone, often sacrificing our }\end{array}$ & 80 & $8.0 \%$ \\
\hline
\end{tabular}


Flourish

maximum good), or some related idea concerning the general improvement of human wellbeing.

\section{Care for Earth \\ CareEarth}

\section{Connection}

Connection

Golden Rule

GoldenRule
This category encompasses responses that emphasise the importance of environmentalism, looking after the planet, and respecting and caring for other species.

This category encompasses responses that emphasise the importance of connections and bonds to others, such as one's family, one's friends, or one's community.

This category encompasses responses that espouse the Golden Rule (do unto others) or some similar guiding axiom (such as the Silver Rule, or the injunction to Do No Harm) human wellbeing (unspecified)

- MinHarm/MaxGoo d

- Animal Rights

- Care/Respect for all Flora \& Fauna

- CareForEarth/Futu re/Environmental legacy

- FamFriendCommu generations."

"We are all connected. Community wellbeing is more important than being rich. Family is everything."

"Human beings are social animals with highly evolved behaviours that ideally serve the collective."

- Golden Rule (do

"I believe the best guiding principle is unto others)/do no harm

"My overall philosophy is along the lines of "live and let live" with protection for vulnerable people and animals. [...] I'm [...] opposed to killing or mistreating animals for food (if alternatives are available) or entertainment."

to treat other people the way you Rule)."

"Not engaging in acts that would harm or otherwise endanger other people." 


\section{Peace \& \\ Collaboration}

PeaceCollab
This category encompasses responses that espouse the value of cooperation, harmony, tolerance and peace between all people, and/or of placing differences to one side for the common good.
- Peace/harmony/tol erance/cooperation

- Collab/Coop/Com municate

"We must all practice empathy, tolerance, and compassion for all to strive for global harmony."

"We should [...] live cooperatively and in harmony of those around us, show respect to others (cooperation and respect will lead to a happy life for all, compared with the alternatives)."

Equality \& kindness

Equality

Equality

\section{Humanism}

Humanism

\section{Kindness \&}

Caring

KindCaring
This category encompasses responses that emphasise the equality of human beings, their inherent value or dignity, the importance of legal or philosophical innovations ensuring such equality is respected, and the general obligation to make society more equal.

This category encompasses responses that fall under the general umbrella of humanism or related worldviews: for example, beliefs that human beings are special, that human history is inherently progressive, that human reason or ingenuity can overcome all problems, and so on.

This category encompasses responses that extoll (/praise) the importance of empathy or concern for others, and/or the importance of caring actions, and helping and supporting others.
- Equality/Inequality /UnivHealthcare/H umanRights/Justice

- Democracy

- Equal/Inequal/Res pect/CareHumans/ HumanRights (Rational care)

- Humanism

- HumAbility/Huma nRelativism

- Teleological (progress/tech/futur e)

- Liberal/Enlightenm

- HumGoodness/Kin dness

- Compass/Empath/ BeKindLoving/Lo ve/NurtureRelships (Intuitive care)
"Treating people of all races, religions and socioeconomic status with dignity and respect."

"I believe that governments should prioritise equal opportunity for health, education and wellbeing for all groups of people on the planet."

"An appreciation of the common nature of human existence and the evolved moral and ethical standards that differentiate populations."

"Humans have additional capacities, either found not at all in other living organisms or only is less developed forms."

"I believe that compassion is paramount in guiding everyday actions and in deciding on public policy."

"I care about people and try to empathise with people who have 
- Human Prosociality

Left-wing political This category encompasses responses that mention a causes

LeftWingPolCauses (regardless of act cause or worldview associated with left-wing politics Includes: "Feminism" + "LGBTQ" + "Socialism" + "Marxism" + "Anarchism".

\section{Progress \&} improvement ProgressImprov
This category encompasses responses that emphasise the importance of gaining knowledge and personal improvement (not to be confused with progress for humanity, which falls under Aggregate flourishing (moral progress)).
- Leftwing politics/socialism/p rogressivism

- Vegetarian

- Pro-Choice

- Pro-Euthanasia

- ProgressEducation

- LearnImprove problems or in situations that I have

been lucky to avoid due to

circumstances I have no control over.'

"I also believe that as a society we should strive to make sure that a minimal standard of living - housing, food, healthcare - is available to everyone."

"I believe in the right to be free of gender roles, sex discrimination, and the rights of children not to be "owned", mis-used, or abused."

"Keep learning all the time, never stop asking questions."

"Listen to people, expose yourself to opposing views, change your mind when you're wrong. Keep learning."

Morality

Acquired Morality This category encompasses responses that emphasise MoralAcquir

- Moral Truths:
"Morality is relative and framed by cultural norms."

"Ethical and moral behaviours are social rather than religious conceptions."

"My belief [is] that social norms and situations are constructed."

"I believe in intrinsic right and wrong."

"I do believe in good and evil, and I that moral behaviour is the result of the cultural or social transmission of norms, or processes of cultural evolution. This includes learning morality from your parents, at school, or from the law.

- Moral Truths: ontogenetic (life experience and cultural transmission) Intuitive 
Morality

unspecified

MoralUnspecif

Rational Morality MoralRation

Secular Morality

MoralSecular
This category encompasses responses that emphasise the importance of doing good/not doing bad, but without specifying what that means. This should also include responses of people who say they believe in 'morality' or 'ethics' without further specifying what/how exactly.

This category encompasses responses that propound the idea that moral behaviour is based on explicit philosophical or scientific or rational reflection. This includes learning from history, but not from personal experience (PersRefl).

This category encompasses responses that emphasise that one does not need to be religious to be moral.
- Doing good (unspecified)/Don't

do bad things (unspecified)

- Do good

(unspecified)

- Moral

Truths:philosophic al/reflective/scient fic

- Morality without religion

believe that either of these traits are inherent in all of us."

"A sense of right and wrong and my

attempts to right wrongs."

"I try to do good."

"Science and reason can help inform

wrong."

"We can try to make the world better according to moral principles arrived at by evidence and the best of human thought."

"Being moral is not owned by religion. Good people will always do the right thing."

"We do not need a virtual spirit in the sky to tell us what we should be doing."

\section{Natural laws \& the here and now}

Gratitude \& Awe GratitudeAwe
Responses that describe the awe one feels for nature, the universe, existence, and the emotional succour (/comfort) derived from thoughts of personal or species-level insignificance.
- Awe at nature/universe/con sciousness

- Gratitude for fluke of existence
"I $[\ldots]$ believe in feeling intense joy

\section{$2.3 \%$} people."

"I am grateful every morning I awake." 


\begin{tabular}{|c|c|c|c|c|c|}
\hline $\begin{array}{l}\text { Human } \\
\text { Insignificance } \\
\text { HumanInsignif }\end{array}$ & $\begin{array}{l}\text { This category encompasses responses that describe } \\
\text { human beings as insignificant on a cosmic (or other) } \\
\text { scale. }\end{array}$ & $\begin{array}{l}\text { - Human } \\
\text { Insignificance }\end{array}$ & $\begin{array}{l}\text { "I believe we are all a tiny part of the } \\
\text { cosmos and life is fleeting." } \\
\text { "Realisation of how insignificant I } \\
\text { am." }\end{array}$ & 32 & $3.2 \%$ \\
\hline $\begin{array}{l}\text { Just One Life } \\
\text { JustOneLife }\end{array}$ & $\begin{array}{l}\text { This category encompasses responses that emphasise } \\
\text { the fleeting nature of life, and/or how it is important } \\
\text { to make the most of it. }\end{array}$ & $\begin{array}{l}\text { - } \text { OneLife } \\
\text { - } \text { Happiness/Joy } \\
\text { - EnjoyHappy }\end{array}$ & $\begin{array}{l}\text { "Without an afterlife, I also feel that } \\
\text { the only legacy one can have is } \\
\text { through good works to better the } \\
\text { world." } \\
\text { "We have one life and you have to } \\
\text { make the most of it." }\end{array}$ & 67 & $6.7 \%$ \\
\hline $\begin{array}{l}\text { Natural Laws } \\
\text { NaturalLaws }\end{array}$ & $\begin{array}{l}\text { This category encompasses responses that talk about } \\
\text { the laws underlying biological or physical systems, } \\
\text { and/or emphasise that humans are subject to the } \\
\text { same laws as the rest of the physical universe. } \\
\text { Includes "Big Bang", and "Evolution". }\end{array}$ & $\begin{array}{ll}\text { - } & \text { Nature } \\
\text { - } & \text { Evolution/BigBang } \\
\text { - } & \text { NaturalLaws/Order } \\
& \text { /Naturalism/Biolog } \\
& \text { y } \\
\text { - } & \text { Stardust/Particles } \\
& \text { (disintegration as } \\
\text { 'return') }\end{array}$ & $\begin{array}{l}\text { "I believe in the Big Bang theory of } \\
\text { the universe and evolution of life and } \\
\text { mankind." } \\
\text { "The certainty that there is no afterlife; } \\
\text { death means back to the stardust we } \\
\text { came from." } \\
\text { "I believe in the laws of physics." }\end{array}$ & 155 & $15.6 \%$ \\
\hline $\begin{array}{l}\text { Philosophical } \\
\text { materialism } \\
\text { PhilMaterialism }\end{array}$ & $\begin{array}{l}\text { This category encompasses responses that there is } \\
\text { only one reality - the natural, physical world. }\end{array}$ & $\begin{array}{l}\text { - Materialism/natural } \\
\text { ism } \\
\text { - This world only / } \\
\text { materialist } \\
\text { ontology }\end{array}$ & $\begin{array}{l}\text { "We only have this physical world." } \\
\text { "I believe in what can be objectively } \\
\text { observed." }\end{array}$ & 82 & $8.2 \%$ \\
\hline \multicolumn{6}{|l|}{ Non-religiosity } \\
\hline $\begin{array}{l}\text { Antitheism } \\
\text { (Antitheism) }\end{array}$ & $\begin{array}{l}\text { This category encompasses responses that explicitly } \\
\text { reject religion, and have negative views on } \\
\text { religion/religious beliefs. }\end{array}$ & $\begin{array}{l}\text { - Antitheist/anti- } \\
\text { religion } \\
\text { - } \text { Elimination of } \\
\text { culture/beliefs/attit } \\
\text { udes impeding }\end{array}$ & $\begin{array}{l}\text { "I believe that religion is basically a } \\
\text { form of mass mind-control and that it } \\
\text { is exercising an increasingly } \\
\text { detrimental influence on the human } \\
\text { race in terms of peace and scientific }\end{array}$ & 77 & $7.7 \%$ \\
\hline
\end{tabular}


human rights/mora progress

- Atheism religious belief, but do not necessarily adopt a negative or critical stance.

\section{No afterlife \\ NoAfterlife}

\section{Reject Superstition \\ (RejectSuperstition) \\ This category encompasses responses that link the rejection of superstitious or religious propositions to mental growth or the acquisition of accurate knowledge.}

- No life after death/afterlife

Reject
unsubstantiated
beliefs
(myths/fairytales/s
uperstitious)

progress. In my opinion, religions neither deserve nor should be given any special respect (e.g. "blasphemy") or privilege (e.g. tax exemption) and should be treated as the nonsense that they are."

"Lastly I find religion to be a millstone around the neck of human progression. It is distasteful in it's primitive, violent, and brutal stories and justifications.

The primary purpose of religion is to control others."

"I believe that $[. .$.$] there is no God or$ any other being that created life."

"There is not a God, nor is there an afterlife."

"I have a humanist understanding of the world, that $[\ldots]$ when we die there is no afterlife."

"Without an afterlife, I also feel that the only legacy one can have is through good works to better the world."

"I don't believe in luck, fate, a greater power of any description. I think that people use these constructs to make life more palatable."

"There is no god, there never was a god, the myths created by humans in 
Secularism

Secularism

This category encompasses responses that emphasise the separation of church and state, advocate resisting against a special place for religious institutions. religious influence on law and policy, or argue

regard to god(s) are just that, myths."

Institutional

"A secular state, including state funded $56 \quad 5.6 \%$ secularism/Separati education."

onofChurch

"I am also strongly opposed to religious indoctrination/infiltration of government entities (schools, police stations, government facilities, etc.) and of medical facilities ("women's centers", pharmacies, hospitals, etc)."

\section{Reflection}

Death is natural

DeathNatural

This category encompasses responses that emphasise accepting the inevitability of death, acknowledge that nothingness is coming for us, and underline the finitude of all biological beings.

Note that this code may frequently be combined with DetachAccept when people have accepted death, and advocate bravery in the face of mortality

Detachment \&

Acceptance

DetachmAccept

This category encompasses responses that advocate the benefits of some form of detachment from lived experience, whether this be achieved through Buddhist philosophy (though see 'Buddhism'),

Stoicism, meditation, a personal stance, or something else. This also includes responses that emphasise the unreality of the self.

\section{Optimism \& \\ Relief}

This category encompasses responses that show belief in optimism and positive thinking, and belief

OptimismRelief
- Face mortality honestly (death stoicism)

"Everyone dies and we all go to the nowhere)."

"Death is part of life. Being dead is no different than not having been born."

- MindfulBuddhStoi
cism

"Buddhist ideas of non-attachment."

"Stoic philosophy a source of inspiration to live a better life."

"I subscribe to positive psychology principles like appreciating the little grateful for something they have done." same place (or rather, we all go things and telling people when you are in a relief from suffering (for death), or, hope, and other forms of optimism. "Things will get better". 


\begin{tabular}{|c|c|c|c|c|c|}
\hline $\begin{array}{l}\text { Personal } \\
\text { Reflection } \\
\text { PersRefl }\end{array}$ & $\begin{array}{l}\text { This category encompasses responses that emphasise } \\
\text { the lessons learned from personal experience. } \\
\text { "Looking inwards", "Self-examination". }\end{array}$ & - Personal Reflection & $\begin{array}{l}\text { things will get better." } \\
\text { "Listening to myself, leaning into my } \\
\text { pain, and acknowledging my feelings." }\end{array}$ & 3 & $0.3 \%$ \\
\hline $\begin{array}{l}\text { Treasured } \\
\text { Memories } \\
\text { TreasMem }\end{array}$ & $\begin{array}{l}\text { This category encompasses responses that describe } \\
\text { treasuring memoires of other people, leaving positive } \\
\text { memories behind, or living on in the minds of those } \\
\text { left behind after one dies. }\end{array}$ & - Treasure memories & $\begin{array}{l}\text { "It is natural to feel badly immediately } \\
\text { after a close relative dies but that } \\
\text { feeling will transform into fond } \\
\text { memory as one realises death is a } \\
\text { natural part of human life." } \\
\text { "We light a candle nightly for those } \\
\text { who have passed that we love." }\end{array}$ & 2 & $0.2 \%$ \\
\hline \multicolumn{6}{|c|}{ Science \& critical thinking } \\
\hline $\begin{array}{l}\text { Critical } \\
\text { Scepticism } \\
\text { CriticScepticism }\end{array}$ & $\begin{array}{l}\text { This category encompasses responses that espouse } \\
\text { the value of a questioning, critical disposition } \\
\text { towards information. }\end{array}$ & $\begin{array}{ll}\text { - } & \text { Skepticism } \\
\text { - } & \text { Rationalism } \\
\text { - } & \text { Critical } \\
& \text { thinking/logic/reas } \\
& \text { on } \\
\text { - } & \text { Philosophical } \\
& \text { reasoning/philosop } \\
& \text { hy/mathematics } \\
\text { - OpenMindedness/ } & \text { ChangeBeliefs }\end{array}$ & $\begin{array}{l}\text { "I believe in weighing available } \\
\text { evidence and coming to the most } \\
\text { reasonable conclusion." } \\
\text { "Know the importance of facts, the } \\
\text { difference between empirical and } \\
\text { anecdotal evidence." }\end{array}$ & 173 & $17.4 \%$ \\
\hline $\begin{array}{l}\text { Science } \\
\text { Science }\end{array}$ & $\begin{array}{l}\text { This category encompasses responses that endorse } \\
\text { science in general, scientific methodology or } \\
\text { perspectives, or scientific expertise and authority. }\end{array}$ & $\begin{array}{l}\text { - } \text { Science } \\
\text { - } \text { Scientific } \\
\text { Method/Evidence/ } \\
\text { Observations/Meth } \\
\text { odological } \\
\text { Naturalism } \\
\text { - Trust } \\
\text { scientific/medical } \\
\text { experts }\end{array}$ & $\begin{array}{l}\text { "I believe in the power of science and } \\
\text { the scientific method." } \\
\text { "My primary way of understanding the } \\
\text { world is based on science and } \\
\text { reasoning." }\end{array}$ & 349 & $35.0 \%$ \\
\hline
\end{tabular}




\section{Spirituality}

Afterlife

Afterlife

This category encompasses responses that show belief in an afterlife (not necessarily specifying anything more about the matter).

- Afterlife (unspecified)

Aliens

Aliens

Other Spirituality SpiritOther

\section{Scientific \\ Mysticism (\& \\ Unity with \\ Universe) \\ ScientifMystic}

This category encompasses responses that emphasise how we are not alone in the universe, and/or in some cases suggest that aliens have intervened in life on earth.

This category encompasses responses that espouse some kind of worldview that would usually be categorised as religious or spiritual.
- SpirOther

- Paganism

This category encompasses responses that emphasise some sense of unity with the universe in scientific terms, mainly as a result of some as-yet undiscovered scientific breakthrough (quantum something-ism), that describe some non-physical,
- Alien life (extraterrestrial or interdimensional)
"I feel so connected to nature on a deeper level than anything else, I just feel that we do have a soul or whatever we want to call it, and that it moves on into a next life."

"I believe based on the overwhelming number of planets in the universe that there is life of some type on many of them."

"I believe in multiple dimensions and that life in all sorts of forms exists in those dimensions but that life may resemble nothing like we experience here."
- Scientific mysticism ('quantum' etc)

- Collective unconscious
"I believe in energy. I believe that energy is affected by energy. I believe I am made of the same energy as the planets and the stars and the plants and the animals and when any of those energies shift or are out of balance they affect everything else including emotional/mental state or connectivity. Pagan-type beliefs mixed with some science."

"There is a creative force. After all, I exist and I didn't bring myself into existence. That does not mean that the force is intelligent or is concerned with me or anything else." my physical body and my 
non-scientific source binding people, living things or the universe together, such as energy, reincarnation, and so on.
- Energy/essence/vis talism/force

- Reincarnation
"I believe in a collective superconscious, that our consciousness transcends space and time but that this is not a "creator" force. I look to advancements in quantum physics to understand how this may work

(entanglement etc). I believe this consciousness can exist outside of our physical bodies."

\section{Truth}

Attainable Truth TruthAttain

Relativism

Relativism

Unattainable

Truth

TruthUnattain
This category encompasses responses that hold that human beings can, eventually, come to possess absolute knowledge of the nature of reality.

This category encompasses responses that disavow (/deny) notions of absolute truth.

This category encompasses responses that, while not relativist, nevertheless believe that absolute knowledge may ultimately be beyond human attainment.
- Truth is out

there/We can know the truth eventually
"I believe in the Big Bang theory of the universe and evolution of life and mankind. Although not all the I's are dotted I believe they eventually will be (e.g. how did life begin?)"

"I understand that science is our best tool for understanding the universe and that it will help provide answers to our most profound questions."

- Truth is liquid/Relative/Pos tmodern

"Understand the truth can be illusive and liquid."

"Even scientific facts change over time."

- Truth/Reality is unknown

"That there are things (forces, dimensions, other forms of "life")

- TruthMayStayUnk nown/Cogn and may never be able to limitationOnKnowl comprehend."

edge 


\begin{tabular}{|c|c|c|c|c|c|}
\hline & & & $\begin{array}{l}\text { "Having evolved for other things } \\
\text { (survival, persuasion), our brains may } \\
\text { not be capable of understanding all the } \\
\text { truths of how the universe works." }\end{array}$ & & \\
\hline \multicolumn{6}{|l|}{ Other } \\
\hline $\begin{array}{l}\text { Art } \\
\text { Art }\end{array}$ & $\begin{array}{l}\text { This category encompasses responses that espouse } \\
\text { the value of practicing, consuming, or appreciating } \\
\text { the arts in all their forms. }\end{array}$ & $\begin{array}{l}\text { The Value of } \\
\text { Art/Aesthetic } \\
\text { experience } \\
\text { - Artistic } \\
\text { achievement / } \\
\text { aesthetic } \\
\text { experience }\end{array}$ & $\begin{array}{l}\text { "I believe that finding stillness, like } \\
\text { being in nature or spending time with } \\
\text { art or music, is essential to emotional } \\
\text { wellness." } \\
\text { "An appreciation of the art, literature, } \\
\text { music and crafts that are our heritage } \\
\text { from the past and of the creativity that, } \\
\text { if nourished, can continuously enrich } \\
\text { our lives." }\end{array}$ & 12 & $1.2 \%$ \\
\hline $\begin{array}{l}\text { Buddhism } \\
\text { Buddhism }\end{array}$ & $\begin{array}{l}\text { This category encompasses responses that state } \\
\text { belief in Buddhism, but also Buddhist concepts such } \\
\text { as 'there is no self', 'there is no reality', and of } \\
\text { course meditation. }\end{array}$ & $\begin{array}{l}\text { - } \quad \text { Meditate } \\
\text { - No self }\end{array}$ & $\begin{array}{l}\text { "I lean towards Buddhism to help me } \\
\text { navigate the world around me. [...] } \\
\text { Listening to ourselves (through } \\
\text { meditation) can guide us forward." }\end{array}$ & 15 & $1.5 \%$ \\
\hline $\begin{array}{l}\text { Conservatism } \\
\text { Conservatism }\end{array}$ & $\begin{array}{l}\text { This category encompasses responses that indicate } \\
\text { they are conservative. }\end{array}$ & $\begin{array}{l}\text { Resist political } \\
\text { correctness/excesse } \\
\text { s of } \\
\text { left/'snowflakism' }\end{array}$ & "I am a conservatist." & 1 & $0.1 \%$ \\
\hline $\begin{array}{l}\text { Negative } \\
\text { Humanity } \\
\text { NegHuman }\end{array}$ & $\begin{array}{l}\text { This category encompasses responses that draw } \\
\text { attention to or include reference to negative aspects } \\
\text { of human nature, such as selfishness, } \\
\text { destructiveness, corruption, foolishness and so on. } \\
\text { "Flawed human nature". This also includes answers } \\
\text { such as "Disconnect from others" and "Trust no } \\
\text { one". }\end{array}$ & 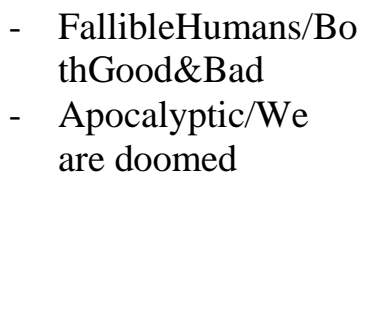 & $\begin{array}{l}\text { "I believe that }[\ldots] \text { selfishness is } \\
\text { innate." } \\
\text { "I believe in the innate kindness of } \\
\text { humanity but accept this can be } \\
\text { damaged or distorted in individuals by } \\
\text { event or example." }\end{array}$ & 33 & $3.3 \%$ \\
\hline & & & $\begin{array}{l}\text { "Getting it wrong is human. Being } \\
\text { nasty or horrible is human." }\end{array}$ & & \\
\hline
\end{tabular}


PREPRINT

Self

Self
This category encompasses responses that emphasise

the importance of the self in some way, such as self-

belief or personal potency.
"Belief in yourself and your own

abilities is $[\ldots]$ important."

"I have an inherent purpose in life merely by existing - it is up to me to be effective in my life if I want any more 'purpose' than that. Nice to be loved by others, but ultimately my only true

obligation in life - on a very deep level - is my loyalty to love myself by to be answerable to myself."

Note. Categories and subcategories ordered alphabetically, with the exception of the Other category which is listed last. Examples are from English-speaking countries (AUS, CAN, GBR, USA), so as not to have translations influence the wording. 
PREPRINT

SM.5 Cultural distance between the countries

\section{Table SM5.1}

Cultural distance between eight of the countries of the study

\begin{tabular}{|c|c|c|c|c|c|c|c|c|}
\hline & Australia & Brazil & Canada & Finland & Great Britain & Netherlands & Turkey & United States \\
\hline Australia & & 0.110 & 0.019 & 0.048 & 0.031 & 0.046 & 0.169 & 0.033 \\
\hline Brazil & 0.110 & & 0.069 & 0.143 & 0.118 & 0.142 & 0.079 & 0.070 \\
\hline Canada & 0.019 & 0.069 & & 0.037 & 0.020 & 0.048 & 0.130 & 0.025 \\
\hline Finland & 0.048 & 0.143 & 0.037 & & 0.045 & 0.063 & 0.203 & 0.074 \\
\hline Great Britain & 0.031 & 0.118 & 0.020 & 0.045 & & 0.047 & 0.200 & 0.056 \\
\hline Netherlands & 0.046 & 0.142 & 0.048 & 0.063 & 0.047 & & 0.217 & 0.082 \\
\hline Turkey & 0.169 & 0.079 & 0.130 & 0.203 & 0.200 & 0.217 & & 0.127 \\
\hline United States & 0.033 & 0.070 & 0.025 & 0.074 & 0.056 & 0.082 & 0.127 & \\
\hline
\end{tabular}

Note. Values shown are cultural $F_{S T}$ values; data combined from the 2005-2009 and 2010-2014 time periods (Muthukrishna et al., 2020) ${ }^{7}$ Data of Denmark and the Czech Republic not available.

\footnotetext{
${ }^{7}$ Muthukrishna, M., Bell, A., Henrich, J., Curtin, C., Gedranovich, A., McInerney, J., \& Thue, B. (2020). Beyond WEIRD psychology: Measuring and mapping scales of cultural and psychological distance. In. https://ssrn.com/abstract=3259613: Social Science Research Network (SSRN).
} 